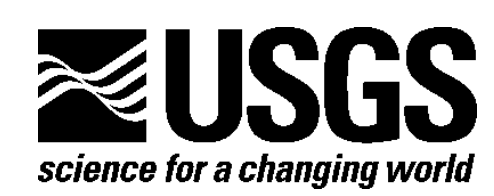

\title{
Sediment-Hosted Gold Deposits of the World-Database and Grade and Tonnage Models
}

By Vladimir I. Berger, Dan L. Mosier, James D. Bliss, and Barry C. Moring

Open-File Report 2014-1074

Version 1.1, June 2014

U.S. Department of the Interior

U.S. Geological Survey 


\section{U.S. Department of the Interior \\ SALLY JEWELL, Secretary}

\section{U.S. Geological Survey \\ Suzette M. Kimball, Acting Director}

U.S. Geological Survey, Reston, Virginia: 2014

Revised: June 2014

For more information on the USGS-the Federal source for science about the Earth, its natural and living resources, natural hazards, and the environment-visit

http://www.usgs.gov or call 1-888-ASK-USGS

For an overview of USGS information products, including maps, imagery, and publications, visit $h t t p: / / w w w . u s g s . g o v / p u b p r o d$

To order this and other USGS information products, visit http://store.usgs.gov

Suggested citation: Berger, V.I., Mosier, D.L., Bliss, J.D., and Moring, B.C., 2014, Sediment-hosted gold deposits of the world—Database and grade and tonnage models (ver. 1.1, June 2014): U.S. Geological Survey Open-File Report 2014-1074, 46 p., http://dx.doi.org/10.3133/ofr20141074.

ISSN 2331-1258 (online)

Any use of trade, firm, or product names is for descriptive purposes only and does not imply endorsement by the U.S. Government.

Although this information product, for the most part, is in the public domain, it also may contain copyrighted materials as noted in the text. Permission to reproduce copyrighted items must be secured from the copyright owner. 


\section{Contents}

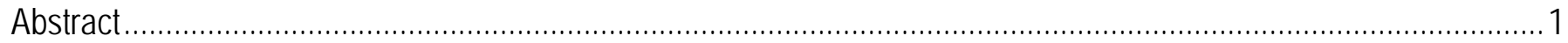

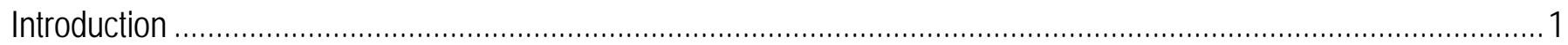

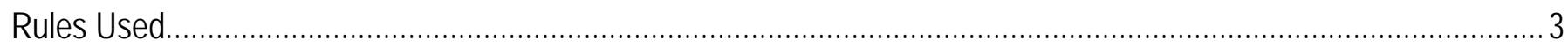

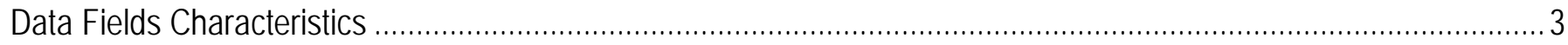

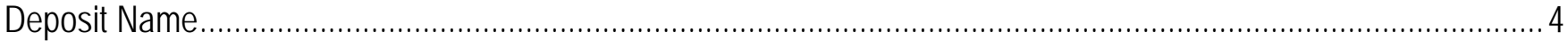

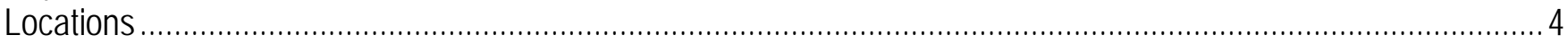

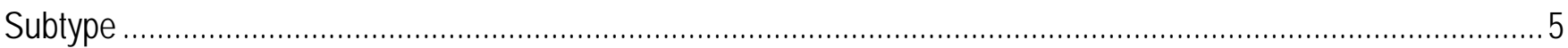

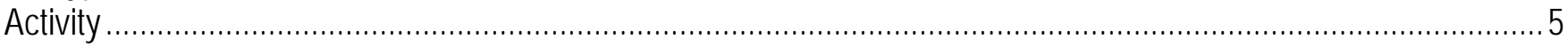

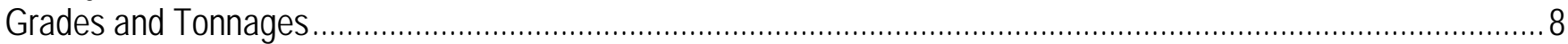

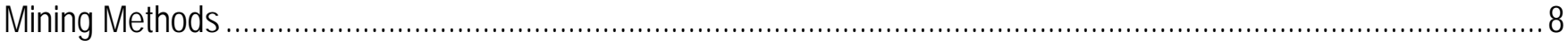

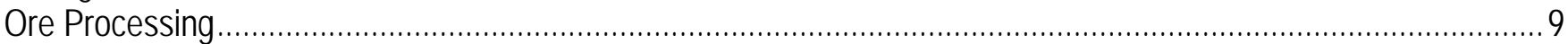

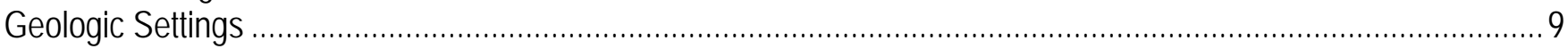

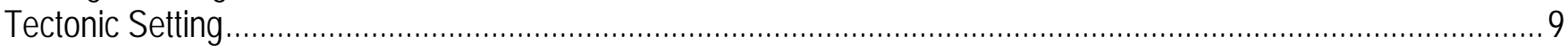

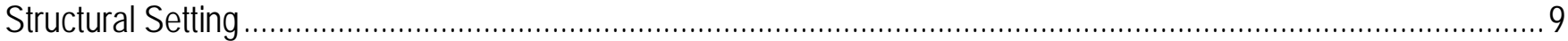

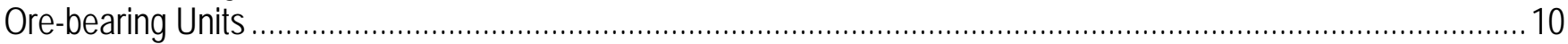

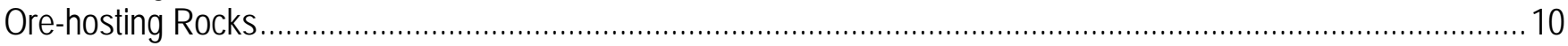

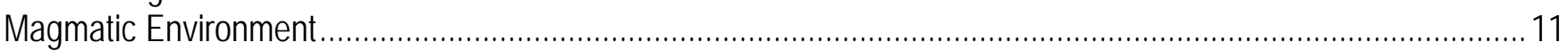

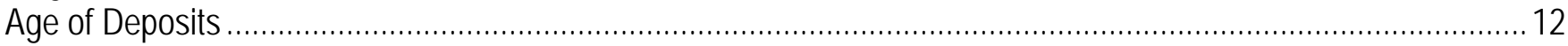

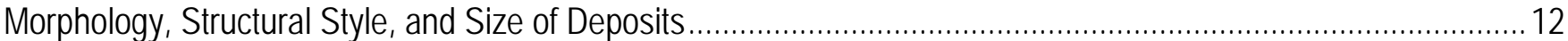

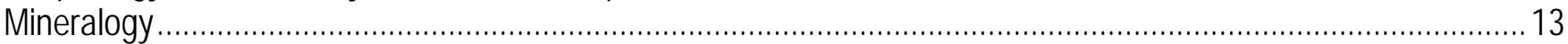

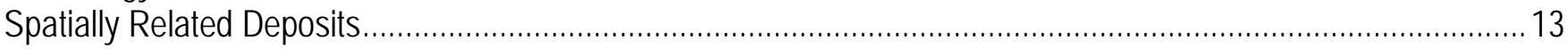

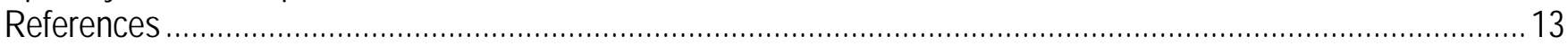

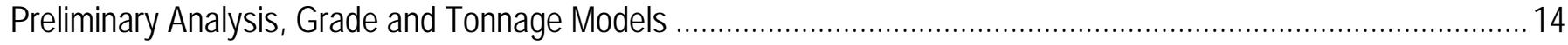

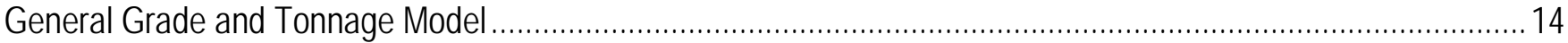

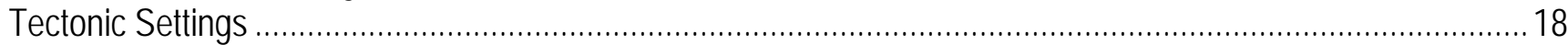

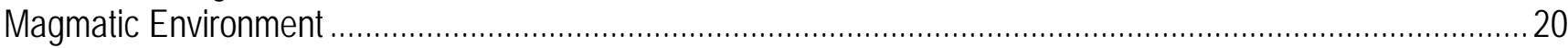

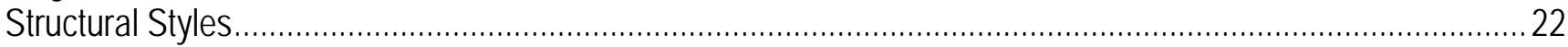

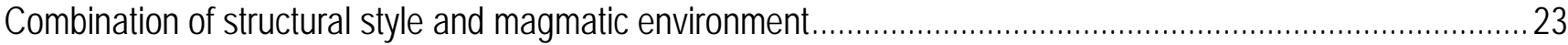

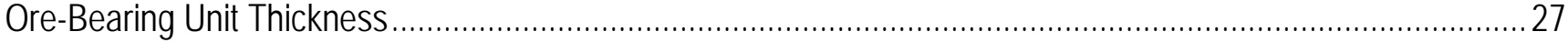

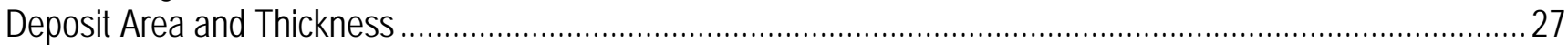

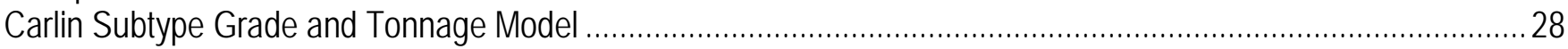

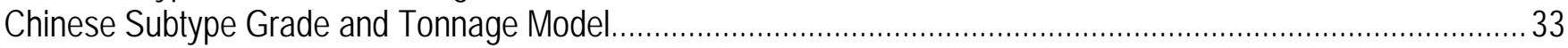

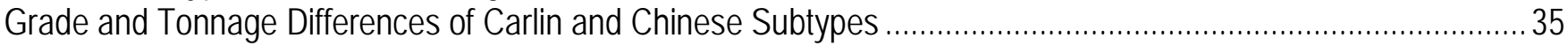

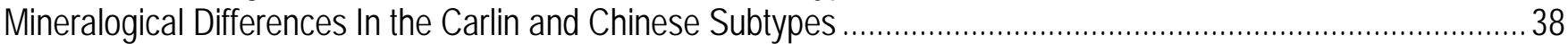

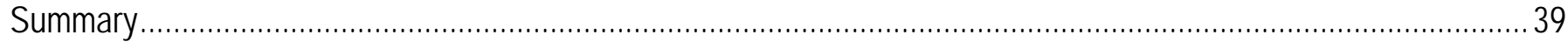

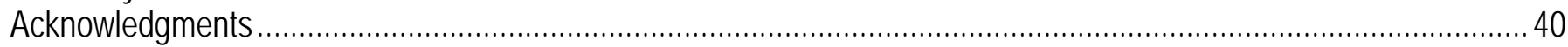

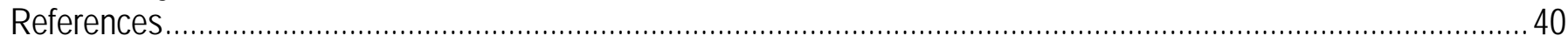

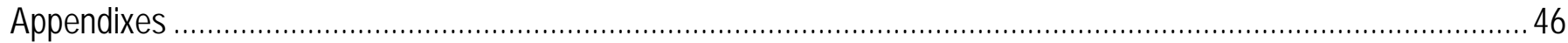

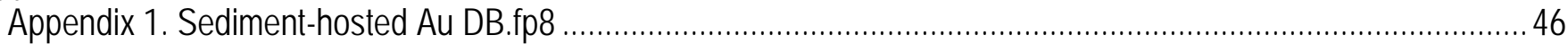

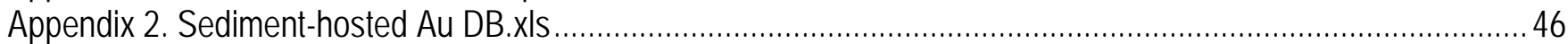

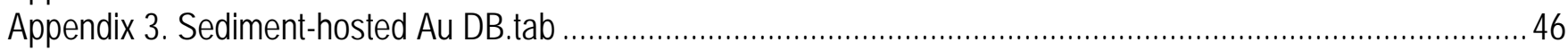

Appendix 4. Reference list to sediment-hosted gold deposits database ............................................................ 46

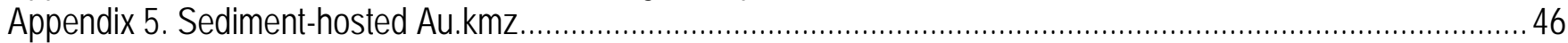

Appendix 6. Definitions of fields of sediment-hosted gold deposits database..................................................... 46 


\section{Figures}

Figure 1. Map showing world location of main sediment-hosted gold provinces and isolated deposits included

in database and grade and tonnage models.

Figure 2. Map showing location of sediment-hosted gold deposits in the Great Basin province, United States, included in database and grade and tonnage models.

Figure 3. Map showing location of sediment-hosted gold deposits in China included in database and grade and tonnage models.

Figure 4. Cumulative frequency plot of ore tonnages and tonnage model for the general sediment-hosted gold deposit type

Figure 5. Cumulative frequency plot of gold grades and gold grade model for the general sediment-hosted gold deposit type

Figure 6. Cumulative frequency plot of silver grades and silver grade model for the general sediment-hosted gold deposit type

Figure 7. Box plots of sediment-hosted gold deposits of different tectonic settings

Figure 8. Box plots of sediment-hosted gold deposits located in amagmatic and magmatic (dike and stock) environments

Figure 9. Cross-sections of selected sediment-hosted gold deposits illustrating how ore bodies relate to dominant structural styles in two different magmatic environments

Figure 10. Box-plots of ore tonnages and contained gold of sediment-hosted gold deposits by four observed combinations of structural style and magmatic environment.

Figure 11. Bivariate plot of tonnages by thickness of all sediment-hosted gold deposits of the United States and China

Figure 12. Cumulative frequency plot of ore tonnages for the Carlin subtype of sediment-hosted gold deposit types

Figure 13. Cumulative frequency plot of gold grades for the Carlin subtype of sediment-hosted gold deposit types

Figure 14. Cumulative frequency plot of silver grades for the Carlin subtype of sediment-hosted gold deposit types

Figure 15. Cumulative frequency plot of ore tonnages for the Chinese subtype of sediment-hosted gold deposit types

Figure 16. Cumulative frequency plot of gold grades for the Chinese subtype of sediment-hosted gold deposit types

Figure 17. Box plots of sediment-hosted gold deposits of Carlin and Chinese subtypes .....................................36

Figure 18. Bivariate plots of the entire sediment-hosted gold deposit population including Carlin and Chinese subtypes

\section{Tables}

Table 1. Abbreviations used in the database and in this report. 3

Table 2. Country names and country codes used in this report..............................................................

Table 3. Distribution of 123 sediment-hosted gold deposits by host-unit age ...............................................10

Table 4. Distribution of 123 sediment-hosted gold deposits by host-unit lithology and host-rock characteristics. 11

Table 5. Statistical summary of grade and tonnage models of sediment-hosted gold deposits............................18

Table 6. Tonnage, gold grades, and contained gold of sediment-hosted gold deposits of different tectonic settings and subsettings.

Table 7. Tonnage and grades of sediment-hosted gold deposits separated into amagmatic and magmatic (dike, stock) environments.

Table 8. Tonnage and grades of sediment-hosted gold deposits of different structural styles. 
Table 9. Proportion of different structural style deposits in areas with different styles (or lack) of intrusive rock...23

Table 10. Tonnage and gold grade in four observed combinations of structural style and magmatic environment of sediment-hosted gold deposits .....

Table 11. Frequency of main minerals grouped by Carlin and Chinese subtypes of sediment-hosted gold deposit types ..... 31

Table 12. Tonnage and gold grades of the Carlin and Chinese subtypes of the sediment-hosted gold deposit types 


\title{
Sediment-Hosted Gold Deposits of the World-Database and Grade and Tonnage Models
}

\author{
By Vladimir I. Berger, Dan L. Mosier, James D. Bliss, and Barry C. Moring
}

\begin{abstract}
All sediment-hosted gold deposits (as a single population) share one characteristic - they all have disseminated micron-sized invisible gold in sedimentary rocks. Sediment-hosted gold deposits are recognized in the Great Basin province of the western United States and in China along with a few recognized deposits in Indonesia, Iran, and Malaysia. Three new grade and tonnage models for sediment-hosted gold deposits are presented in this paper: (1) a general sediment-hosted gold type model, (2) a Carlin subtype model, and (3) a Chinese subtype model. These models are based on grade and tonnage data from a database compilation of 118 sediment-hosted gold deposits including a total of 123 global deposits. The new general grade and tonnage model for sediment-hosted gold deposits $(\mathrm{n}=118)$ has a median tonnage of 5.7 million metric tonnes $(\mathrm{Mt})$ and a gold grade of 2.9 grams per tonne $(\mathrm{g} / \mathrm{t})$. This new grade and tonnage model is remarkable in that the estimated parameters of the resulting grade and tonnage distributions are comparable to the previous model of Mosier and others (1992). A notable change is in the reporting of silver in more than 10 percent of deposits; moreover, the previous model had not considered deposits in China. From this general grade and tonnage model, two significantly different subtypes of sediment-hosted gold deposits are differentiated: Carlin and Chinese. The Carlin subtype includes 88 deposits in the western United States, Indonesia, Iran, and Malaysia, with median tonnage and grade of 7.1 Mt and $2.0 \mathrm{~g} / \mathrm{t} \mathrm{Au}$, respectively. The silver grade is $0.78 \mathrm{~g} / \mathrm{t} \mathrm{Ag}$ for the $10^{\text {th }}$ percentile of deposits. The Chinese subtype represents 30 deposits in China, with a median tonnage of 3.9 Mt and medium grade of $4.6 \mathrm{~g} / \mathrm{t} \mathrm{Au}$. Important differences are recognized in the mineralogy and alteration of the two sediment-hosted gold subtypes such as: increased sulfide minerals in the Chinese subtype and decalcification alteration dominant in the Carlin subtype. We therefore recommend using the appropriate grade and tonnage model presented in this study for mineral resource assessments depending on the geologic and mineralogical data available for a region. Tonnage and contained gold within the general sediment-hosted gold model are analyzed based on major geologic features such as tectonic setting and magmatic (dikes, sills, and stocks) or amagmatic environment. The results show a significant difference in tonnage and contained gold, with higher median values in deposits spatially associated with igneous rocks, regardless of structural style of the deposit. These results suggest that magmatic environments control mineralization intensity —an important consideration in the regional assessment of prospective areas for sediment-hosted gold deposits.
\end{abstract}

\section{Introduction}

According to our database compilation of geologic and tonnage and grade data, sediment-hosted gold deposits in the United States produced approximately 4,175 tonnes of gold starting in the early 1960s through 2011. This figure is close to the 4,500 tonnes of gold estimated by Teal and Jackson (1997), Muntean (2006), and Driesner and Coyner (2011). China is also one of the world's current leading gold producers with a total annual production of 345 tonnes in 2010 (U.S. Geological Survey, 2011). Gold production in China includes that from their sediment-hosted gold deposits, though most data are not reported. 
Sediment-hosted gold deposits are characterized by micro-grained (micron-sized) disseminated gold mineralized zones in altered, layered sedimentary rocks locally penetrated by igneous dikes and sills (Berger, 1986; Berger and Bagby, 1991; Ressel and Henry, 2006). These deposits were first discovered in Nevada in the early 1960s and soon became the main gold producers in the United States (Roberts, 1966; Cline and others, 2005). They were called "Carlin-type” deposits after the nearby town of Carlin, Nevada. About 100 Carlin-type deposits are known to be present within the Great Basin of Nevada as well as in southern Idaho and western Utah (Roberts, 1966; Hofstra and Cline, 2000; Cline and others, 2005; Muntean and others, 2011). From the 1970s to 1980s, more than 30 comparable sediment-hosted disseminated gold deposits were discovered in China (Hu and others, 2002; Mao and others, 2002).

This report includes a database compilation of 123 explored sediment-hosted gold deposits. Of these deposits, 118 have reliable data about reserves, resources, and gold production and are suitable for modeling purposes. Descriptive and quantitative information about geology, deposit size, and commodity grade (appendix 1) were compiled from published sources and Web sites, as well as recent issues of technical journals current through March 2012. We present our database compilation of sediment-hosted gold deposits in File Maker Pro, Microsoft Excel, and tab-delimited text formats. Data fields include: location, subtypes, development state, tonnages and grades, mining and processing methods, geologic setting, deposit morphology and structural groups, and deposit age. All references cited in the database (appendixes 1-3) are included in appendix 4. Location information for deposits was plotted in a geographic information system (GIS) to check latitude and longitude. A data file to plot deposits in Google Earth is included in appendix 5 and each deposit is tagged with geographic coordinates, tonnage, and grade. Brief definitions of the database fields are placed in appendix 6. As presented, the information in the database is available to a broad audience.

Most sediment-hosted gold deposits involved in our analysis are well explored and many deposits are entirely mined or depleted. These deposits yield reliable data on tonnages and grades used in the statistical analysis for the new grade and tonnage models. Statistical tests were performed using JMP 8 software (JMP, 2002) to determine if sediment-hosted gold deposits could be categorized based on size, gold and silver grades, geographic location, magmatic environment, and (or) deposit morphology. Statistically significant differences among these variables may help separate tonnage-grade models into subtypes. These tonnage-grade models are likely to be stable given: (1) tonnage and gold grades are not significantly different from a lognormal distribution, (2) at least 20 deposits are used, (3) the standard deviation of tonnage (in logarithms) is less than 1.0, and (4) there are no significant correlations between tonnage and grade (Singer and Menzie, 2010).

Mineral-deposit models integrate diverse geoscience information on geology, mineral occurrences, geophysics, and geochemistry used in resource assessments and mineral exploration. Deposit models allow recognition of important features (such as grades and tonnage and geological features) and demonstrate how common various features are. Mineral-deposit models are important in exploration planning and quantitative resource assessments for two reasons: (1) grades and tonnages among deposit types vary significantly, and (2) deposits of different types are present in distinct geologic and (or) tectonic settings that can be identified from geologic maps (Singer and Menzie, 2010). Well-designed deposit models allow geologists to deduce the possible presence of mineral-deposit types in a given geologic environment, and grade-tonnage models allow mineral economists to estimate economic viability of different mineral resources. Thus, mineral-deposit models are pivotal in presenting geoscience information to explorationists, policy makers, and others.

Discovery, development, and expansion of mines in sediment-hosted gold deposits requires updated gold grade-tonnage models (Bagby and others, 1986; Mosier and others, 1992). This paper presents three new grade-tonnage models for sediment-hosted gold deposits: (1) a general sedimenthosted gold type model, (2) a Carlin subtype model, and (3) a Chinese subtype model. First, we will discuss deposit type, rules and methods used for data compilation, and data fields of the database. Then, 
we will present preliminary data analyses for the three new grade-tonnage models, discuss their similarities and differences, and finally, summarize the results of the new grade-tonnage models for sediment-hosted gold deposits.

\section{Rules Used}

A sediment-hosted gold deposit is a type of mineral deposit. A mineral deposit is defined as a mineral occurrence of sufficient size and grade that might have economic potential (Cox and Singer, 1986). Deposits sharing a wide variety and large number of attributes are characterized as a "type," and a model representing that type can be developed.

The spatial criteria for defining a deposit are important to consider during the data-gathering stage. Grade and tonnage data are available at various levels of spatial aggregation for districts, deposits, and mines. In this study, grade and tonnage data for mineralized bodies of rock are aggregated if they are (or were prior to mining) within 200 meters of each other. This is less than the 500-meter spacing rule used in data preparation by Mosier and others (1992). The combined mineralized rocks were considered a deposit for purposes of analysis and modeling and this aggregation affects the number of deposits estimated in assessments of undiscovered deposits. The 200-meter threshold distance was determined empirically by studying the spatial distribution of sediment-hosted gold mineralized bodies in northeastern Nevada. The effects of the application of this rule are illustrated by "Betze-Post (Goldstrike)” deposit, which includes closely spaced mineralized bodies at Bazza, Deep Post, Long Lac, Screamer, West Bazza, and elsewhere, that were discovered and mined separately in different periods (Bettles, 2002; Leonardson and Rahn, 1996; Streiff, 2000; Teal and Jackson, 1997; Ye and others, 2003). In such cases, previously named deposits that were combined are listed in the data field labeled "Includes" in the database.

\section{Data Fields Characteristics}

Data on explored sediment-hosted gold deposits used in this study are found in appendix 1. (Sediment-hosted Au DB.fp8), appendix 2 (Sediment-hosted Au DB.xlsx), and appendix 3 (Sedimenthosted Au DB.tab), which are FileMaker Pro 8, Excel, and tab-delineated text files, respectively. The fields of FileMaker Pro 8 conform to columns in Excel. Data fields in the files are described below. Common abbreviations used in the database and in this paper are listed in table 1 and appendix 6 contains definitions of the data fields. Besides 'n.d.', blank fields also indicate no data available.

Table 1. Abbreviations used in the database and in this report.

\begin{tabular}{l|l}
\hline \multicolumn{1}{c|}{ Abbreviation } & \multicolumn{1}{c}{ Explanation } \\
\hline n.d. & "no data," "not detected,” or "not defined" in various fields \\
t, Kt, Mt & tonnes (metric tons), thousand tonnes, million tonnes \\
OP & open pit \\
UG & underground \\
JV & joint venture \\
re & reserve \\
res & resource \\
pr & Production \\
to & total \\
VB & initials of Vladimir Berger marking notes, primarily in the Comments field \\
\hline
\end{tabular}




\section{Deposit Name}

The most recently used deposit name is listed in the "NameDeposit" field. There is another field, "OtherNames," which contains alternative names that have been used for the deposit. A third field, "Includes," provides the names of deposits and sites that have been combined with the primary deposit because of the 200-meter minimum separation rule described above.

\section{Locations}

A number of fields are provided to show the deposit's location. "Country" is the nation in which the deposit is found and "StateProvince" identifies the second order government unit. "CountryCode" is an abbreviated version of the country name combined with state in some countries (table 2). The field informally named "DepositCluster" shows the deposit's spatial grouping as used by local geologists, for instance, Carlin Trend of Nevada or Western Qinling belt of China. Deposit clusters may include several ore districts; clusters generally are subordinate to province. Degrees, minutes, and seconds of longitude and latitude are provided in separate fields. Decimal degrees of latitude ("LatitudeDecimal”) and longitude ("LongitudeDecimal”) are calculated from the degrees, minutes, and seconds fields. Southern latitudes and western longitudes are negative values. The "LocationAccuracy” data field includes two categories: 'Accurate' is a verified location based on a surface mine, tailings, or surface disturbance supported with detailed map location. 'Approximate' is for a general location given by description or from a large-scale map or where exact surface indications could not be found, but it is reasonably certain that it is very close to the target location.

Table 2. Country names and country codes used in this report.

\begin{tabular}{|c|c|c|}
\hline Country & State or Province & $\begin{array}{c}\text { Country } \\
\text { code }\end{array}$ \\
\hline China & & CINA \\
\hline Indonesia & & INDS \\
\hline Iran & & IRAN \\
\hline Malaysia & & MLYA \\
\hline United States & Idaho & USID \\
\hline United States & Nevada & USNV \\
\hline United States & Utah & USUT \\
\hline
\end{tabular}

Longitudes and latitudes of all localities were visually checked and corrected using Google Earth 5.1. Provinces and all sediment-hosted gold deposits included in the database are located on a world map (fig. 1) and are plotted, along with grade and tonnage information, on the Google Earth 5.1 image using the "Sediment-hosted Au.kmz" file (appendix 5). 


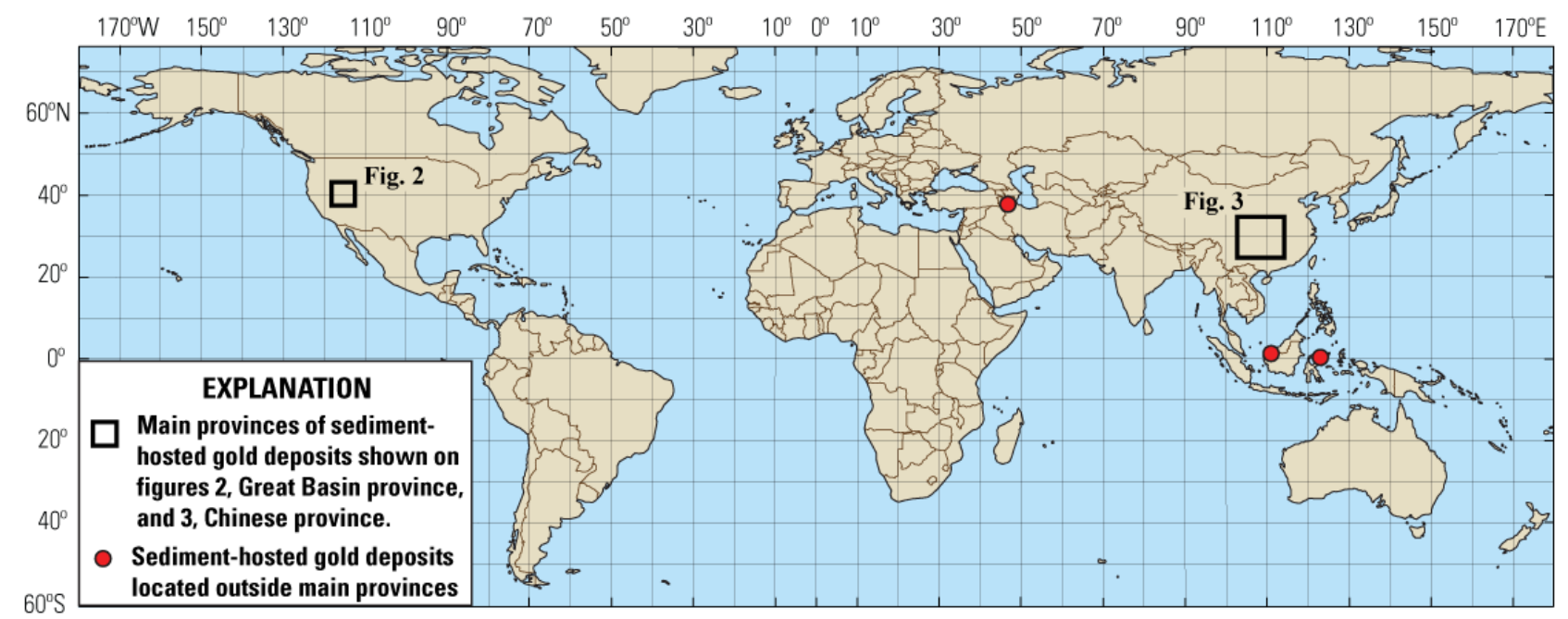

Figure 1. Map showing world location of the main sediment-hosted gold provinces and isolated deposits included in the database and grade and tonnage models.

Although isolated sediment-hosted gold deposits have been discovered in Indonesia, Iran, and Malaysia, most deposits are located in the United States and China. Potential sediment-hosted gold deposits elsewhere in the world, with little or no available information, are excluded from our database. In the Great Basin province of the western United States, sediment-hosted gold deposits are concentrated in Nevada along three trends (Battle Mountain-Eureka, Carlin, and Getchell) and two districts (Jerritt Canyon and Pequop) (fig. 2) (Bedell and others, 2010; Cline and others, 2005). A few deposits are located outside of these main trends and districts and some are scattered across adjoining areas of Idaho and Utah. Four known deposits in Utah, including the Mercur deposit, are localized on flanks of the Bingham porphyry system shown in figure 2.

Sediment-hosted gold deposits of China (fig. 3) are present in the western and southwestern provinces mostly in two clusters: (1) West Qinling belt in Gansu and Sichuan provinces, and (2) DiangQian-Gui, the so called "Golden Triangle” deposit cluster (Hu and others, 2002; Mao and others, 2002; Peters and others, 2002a, 2002b, 2007) extending through Guangxi, Guizhou, and Yunnan provinces.

\section{Subtype}

Sediment-hosted gold deposits are divided into two subtypes, Carlin or Chinese, and are listed in the "Subtype" field. These subtypes are described and statistically analyzed in the Preliminary Analysis section. All of the deposits in China (33) are of the Chinese subtype. All of the deposits in the United States (87), and deposits in Iran, Malaysia, and Indonesia are of the Carlin subtype.

\section{Activity}

Mining activity at the deposits is described by four fields: "OwnerOperator," "Status," "DiscoveryDate," and "StartUpDate." "OwnerOperator" contains the latest owner information. "Status" describes the current state of activity, which is described below. "DiscoveryDate" and "StartUpDate" are self-explanatory. The "Status" field contains four kinds of activities: mining operations (39 deposits), exploration (33), inactive (45), and not reported (6, which are designated as 'n.d.' in the database). Thus, 72 sediment-hosted gold deposits (about 59 percent of our database) were actively mined or under exploration at the time of this report. 


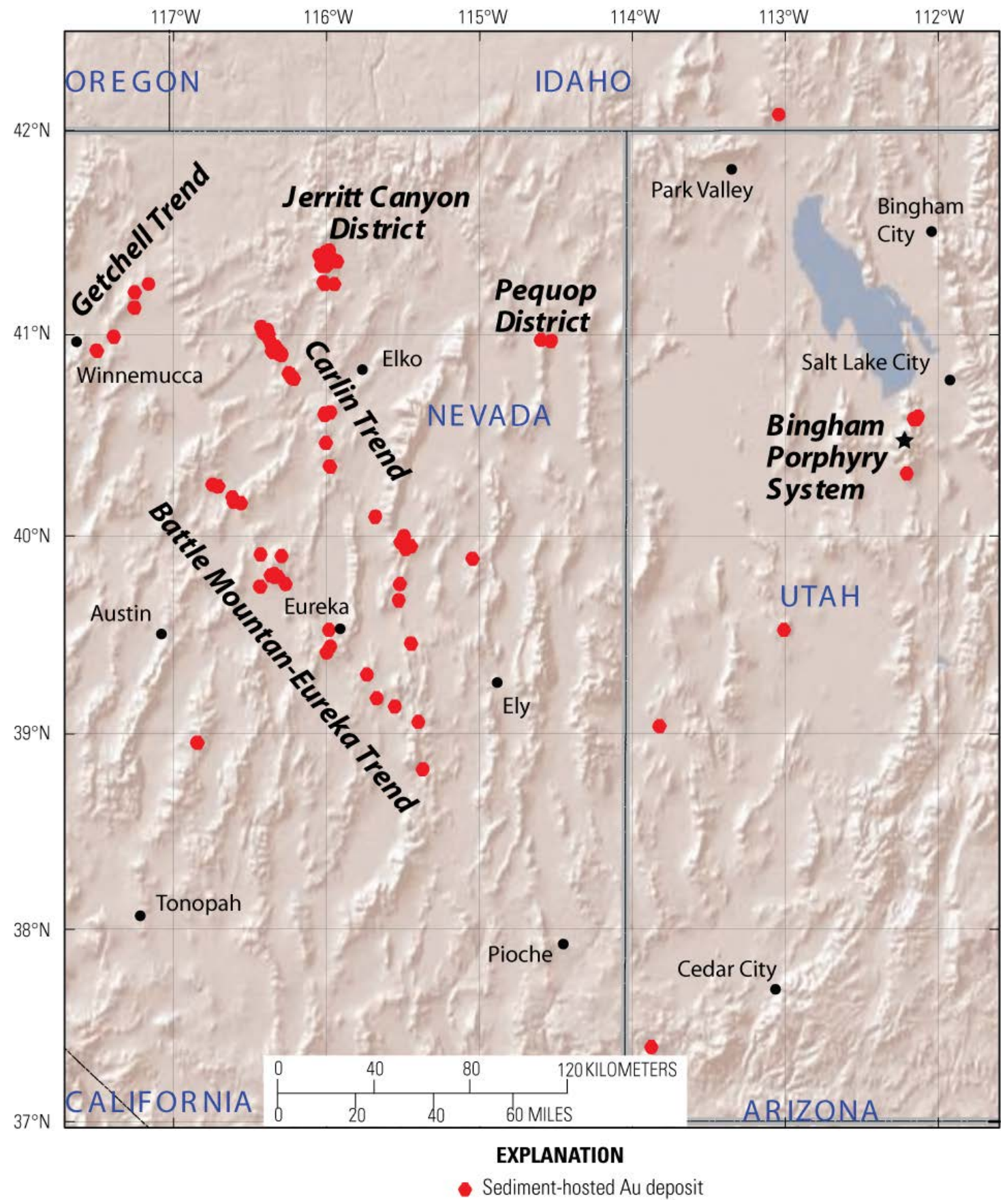

Figure 2. Map showing location of sediment-hosted gold deposits in the Great Basin province, United States, that are included in the database and grade and tonnage models. 


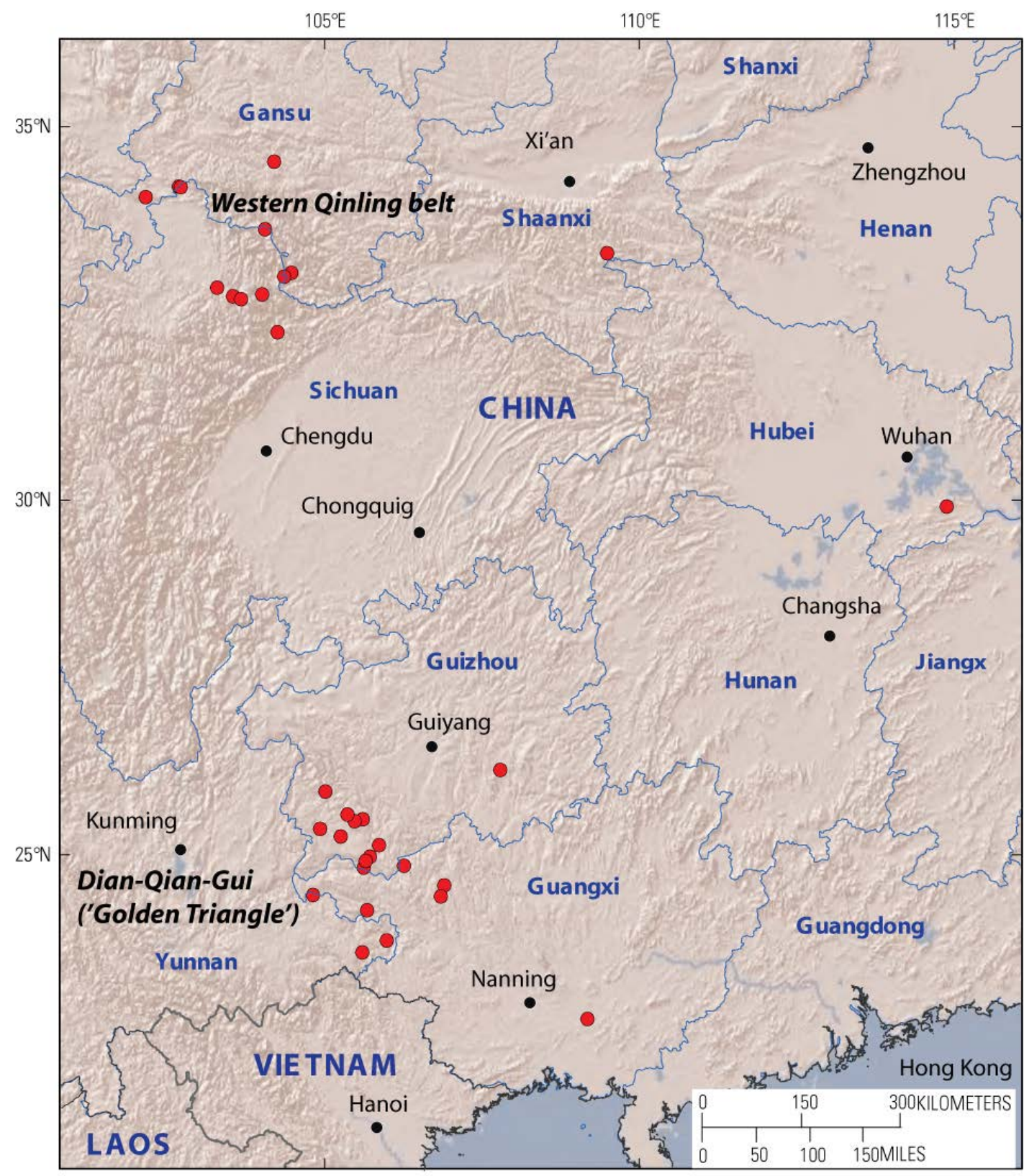

EXPLANATION

- Sediment-hosted Au deposit

Figure 3. Map showing location of sediment-hosted gold deposits in China that are included in the database and grade and tonnage models. 


\section{Grades and Tonnages}

Data gathered for each deposit include average gold and silver grades and tonnages based on total production, reserves, and resources at the available lowest possible cutoff grade at the time (Singer and Menzie, 2010). Grades and tonnages are given separately (when possible) for open pit (OP) and underground (UG) operations - otherwise, the deposit total is used. All tonnages reported here are in millions of metric tonnes (Mt). Gold and silver grades that were reported in the original sources as ounces per short ton have been converted into grams per tonne $(\mathrm{g} / \mathrm{t})$. Three significant digits are used for grades and tonnages.

The following grade and tonnage data fields are presented in the database:

OP reserve data are represented by data fields "ReserveTonnageOP,” “AuReOPGrade,” “AuReOPCutoff,” and "ReserveOPYearCat” (year and category). Similar data fields are used for UG reserve data where 'UG' replaces 'OP' in the data field name (for example, "ReserveTonnageUG”).

OP and UG resources are defined "ResourceTonnageOP” and "ResourceTonnageUG”, and by data fields similar to reserves but with the abbreviation 'Res' (for example, "AuResOPGrade” and “AuResUGGrade”).

UG reserves and resources are estimated in 30 deposits and 25 percent of them contain OP and UG reserves and resources with distinct gold grades and tonnages. Each of these categories is characterized by similar but separate sets of data fields ("Reserve OPYearCat," "Reserve UGYearCat," "Resource OPYearCat," "Resource UGYearCat”) including year, general definition of estimated reserves, and resources similar to definitions required by the National Instrument 43-101 of the Canadian Securities Administrators (2001). Additionally, reserves are defined as proven, probable, possible, and (or) historic. Resources are determined as measured, indicated, inferred, geologic, and (or) historic.

Production data are in data fields: "ProductionTonnage,” “AuPrGrade,” “AgPrGrade,” and "ProductionYear."

Calculated summary data fields include: “TotalTonnage,” “AuToGrade,” “AgToGrade,” and "ContainedAuTonne.” This group of data fields includes total grade and tonnage and contained gold data that are summarized reserves, resources, and production and used for grade and tonnage modeling. Silver grades are compiled in the field of “AgToGrade” and are also used in calculations. If unavailable, silver grades are treated as zero in this field and are shown as a blank in non-calculating fields. Silver grades are reported in only 29 deposits. The "Comments" field contains supplementary information about Au, Ag, PGE, and other commodity grades when available.

The field "SourceTonnGrade" indicates sources of tonnage-grade data, corresponding to "References.” If required, more detailed information about reserves, resources, and production is placed in "Comments." Ore bodies that are open on the flanks or at depth are also noted in the "Comments" field.

\section{Mining Methods}

Mining methods are defined by the individual circumstances of each deposit, and the primary determinant is the distribution of oxidized ores. The fields used to record mining methods are 'Openpit' and 'Underground' as 'yes' or 'no' responses (the latter indicated by an empty field). Sediment-hosted gold deposits of the Great Basin province commonly include deposits highly oxidized near the surface. Eighty percent of deposits contain oxidation zones that range in depth from tens of meters to more than 300 meters and require the use of open-pit mining methods. Underground mining operations occur at 30 percent of deposits and are commonly focused on mining deep refractory sulfide ores as extensions of prior open-pit operations. These percentages also hold true for the China deposits. 


\section{Ore Processing}

Three data fields are related to gold extraction technology: "HeapLeach," "CrushingMilling," and "Recovery_Au\%." "HeapLeach” and "CrushingMilling” data fields indicate hydrometallurgical and concentrator methods of ore processing, respectively, and are designed as 'yes' or 'no' responses (the latter indicated by an empty field). The "Recovery_Au\%" field reports the percentage of gold recovery or no data available (n.d.). When two numbers are present in the "Recovery_Au\%" field, the first number indicates heap-leach gold recovery and the second number reports crushing-milling gold recovery; otherwise, gold recovery percentage is explained in the "comments" field. The heap-leach method of gold extraction, especially from oxidized ores mined by open pit, is reported in 84 deposits (67 percent). Crushing, milling, and subsequent conventional metallurgical processing are mostly used for refractory sulfide ores in 62 deposits (51 percent). In the dataset, gold recoveries from heap leaching and metallurgical processing range from 60 to 79 percent and from 82 to 98 percent, respectively. In three of the Chinese deposits using the metallurgical process reported gold recovery range from 82 to 93 percent.

\section{Geologic Settings}

Geologic settings for sediment-hosted gold deposits are described by the following data fields: "TectonicSetting," "StructuralSetting," OrebearingUnit,” and "OreHostRock." Magmatic environment is characterized by the fields of "IntrusiveRock," "DikeSill," "StockPluton,” and "IntrusiveRockAge_Ma." Deposits are characterized by other fields such as "DepositShapeStyle," "BedLens," "FaultZone," "VeinStockwork," and “OreBreccia.” Deposit area parameters are shown in the fields “DepositArea_SqKm,” “DepositLength_km,” "DepositWidth_km,” and “DepositThick_m.” Mineralogical composition of deposits is described in the fields "OreMineral," "GangueMineral," "GoldContainingMineral," “GoldParticleSize_micron,” and “Alteration.” Age of deposits is expressed by the two fields "DepositAgeGeologic" and "DepositAgeChronologic." Spatially associated deposits are shown in the field "AssocDepositsLess10km."

\section{Tectonic Setting}

The "TectonicSetting” data field describes the regional tectonic setting for each sediment-hosted gold deposit based on names reported in the literature and shown on maps, including cratons and fold belts. All regional tectonic units in this study are contemporary units bearing sediment-hosted gold deposits. Tectonic units are described in the field in the order from large to smaller scaled units. Deposits in the craton group are assigned to one of the three subsettings: platform (70 deposits), foreland basin (22), and imbricate structure (13). The regional setting of the Goldstrike deposit, Utah, occurring in an overlapping Tertiary sequence, is uncertain. Deposits in the fold belts group include those in fold belts (15), magmatic arcs (1), and volcanic island arcs (1). More detailed descriptions and statistical characteristics of sediment-hosted gold deposits confined to these tectonic categories are in the "Preliminary Analysis" section, supporting the general grade and tonnage model.

\section{Structural Setting}

"StructuralSetting" of deposits in original data sources is commonly described using diverse terms and scales. It is difficult to classify types of structural settings in mineralized areas; therefore, this field contains a general description of the structural features for each sediment-hosted gold deposit or for their groups. Detailed descriptions of ore-controlling structures are found in the "DepositShapeStyle" field. There are approximately 79 (64 percent) sediment-hosted gold deposits associated with fault systems or fault zones. Most of them are high-angle normal faults but reversed and strike-slip faults also are known. A smaller group of 15 (12 percent) deposits have 'reactivated faults' that were primarily 
formed during the Paleozoic by multi-stage reactivated faulting (Moore, 2001; Muntean and others, 2007). Thrust structures and shear zones, including bedding-plane shear zones, are typical, especially in the imbricate tectonic settings (see above). Different sorts of such compressional structures are reported in 23 (19 percent) deposits. Fold structures as a deposit-controlling factor are mostly described in China deposits where 14 deposits (42 percent of China deposits) are defined by domes and anticlines.

\section{Ore-bearing Units}

Mineralized stratigraphic units (“OrebearingUnit”) are recorded here using the same terms as the published maps and reports. Local names of units and their geologic ages are combined. Table 3 lists the ages of time-stratigraphic units in which sediment-hosted gold deposits are present. The one notable observation is that 36 percent of the reported deposits are in Silurian-Devonian age rocks, found mostly in the north Carlin Trend in northeastern Nevada. Less prominent are 11 percent of reported deposits in Triassic age rocks in China. Data on local stratigraphic names, compositions, and ages of ore-bearing units are supplemented by the thickness field "OrebearingUnitThick_m.” Thicknesses range from 20 to greater than 1,000 m, with thicknesses of 20 to $250 \mathrm{~m}$ characteristic of more than 75 percent of deposits.

Table 3. Distribution of 123 sediment-hosted gold deposits by host-unit age.

[Count, number of deposits; \%, percent of deposits within the host-unit age. Note that many deposits occur in host units of more than one age.]

\begin{tabular}{|c|c|c|c|}
\hline Host-unit age & Count & $\%$ & Comment \\
\hline Tertiary & 2 & 2 & \\
\hline Cretaceous and Jurassic & 2 & 2 & \\
\hline Permian-Triassic & 15 & 11 & Including 2 deposits in Permian-Triassic units \\
\hline Pennsylvanian-Permian & 12 & 10 & $\begin{array}{l}\text { Including } 2 \text { deposits in Pennsylvanian-Permian } \\
\text { units }\end{array}$ \\
\hline $\begin{array}{l}\text { Carboniferous and } \\
\text { Devonian-Mississippian }\end{array}$ & 22 & 18 & $\begin{array}{l}\text { Including } 2 \text { deposits in Carboniferous units, and } 7 \\
\text { deposits in Devonian-Mississippian units }\end{array}$ \\
\hline $\begin{array}{l}\text { Devonian and Silurian- } \\
\text { Devonian }\end{array}$ & 44 & 36 & $\begin{array}{l}\text { Including } 18 \text { deposits in Devonian units, and } 26 \\
\text { deposits in Silurian-Devonian units }\end{array}$ \\
\hline $\begin{array}{l}\text { Ordovician and Ordovician- } \\
\text { Silurian }\end{array}$ & 13 & 10 & $\begin{array}{l}\text { Including } 2 \text { deposits in Ordovician units, and } 20 \\
\text { deposits in Ordovician-Silurian units }\end{array}$ \\
\hline Cambrian & 12 & 10 & \\
\hline Precambrian & 1 & 1 & \\
\hline
\end{tabular}

\section{Ore-hosting Rocks}

The field designated “OreHostRock” contains information about host-rock lithology. Host rocks associated with the deposits are listed in this field and summarized in table 4. Three types of sedimentary rocks - limestone, mudstone, and siltstone-host more than 80 percent of deposits. Impure argillaceous, carbonaceous, and silty limestones are reported as host rocks for 68 (55 percent) of the deposits. Fine-grained siliciclastic host rocks include impure calcareous and carbonaceous varieties of mudstone and siltstone. Argillic, calcareous, dolomitic, and silty sandstone is reported in 14 (11 percent) deposits. There are 17 deposits (14 percent) that include descriptions of stratabound collapse breccia and silicified breccia controlled by faults and (or) stratigraphy. Seventeen deposits (14 percent) include descriptions of intrusive dikes and sills of various compositions where gold mineralization is mainly localized along contacts of intrusive bodies. 
Table 4. Distribution of 123 sediment-hosted gold deposits by host-unit lithology and host-rock characteristics.

[Count, number of deposits; \%, percentage of deposits with host-unit lithology. Numbers in parenthesis indicate number of observations reported. Note that many deposits are associated with more than one rock type.]

\begin{tabular}{|c|c|c|c|}
\hline Host-unit lithology & Host-rock characteristics & Count & $\%$ \\
\hline limestone & $\begin{array}{l}\text { argillaceous (6), bioclastic, calcarenite, carbonaceous } \\
\text { (25), debris flow, dolomitic, laminated, massive, } \\
\text { micritic, reef, siliceous, silty (37), wispy }\end{array}$ & 81 & 66 \\
\hline siltstone & calcareous (25), carbonaceous (16), dolomitic & 61 & 50 \\
\hline breccia & collapse, dolomitic, karst, sedimentary, silicified & 17 & 14 \\
\hline dolomite & & 15 & 12 \\
\hline basalt, tuff, tuffite & & 4 & 3 \\
\hline
\end{tabular}

In the Great Basin province, the majority (73 deposits, or 84 percent) of sediment-hosted gold deposits are located in Paleozoic sedimentary rocks of the autochthonous (lower plate) eastern assemblage and are exposed by tectonic windows through (or below) the regional Roberts Mountains thrust (Roberts, 1966). Some deposits, mostly related to imbricate structure (see "Tectonic Setting” section), are hosted by chert, basalt and tuff, as well as clastic rocks, in which gold-mineralized rocks extend through western assemblage rocks of the allochthonous plate.

\section{Magmatic Environment}

Magmatic intrusions are important in the development of sediment-hosted gold deposits (Arehart, 1996; Bettles, 2002; Christensen, 1993; Cline and others, 2005; Ressel and Henry, 2006; Sillitoe and Bonham, 1990). Database fields related to intrusive rocks observed with deposits include: "IntrusiveRock," "IntrusiveRockAge_Ma,” and two fields related to intrusive-rock morphology, "DikeSill” and "StockPluton,” with 'yes' or 'no' responses (the latter indicated by an empty field). The 'n.d.' abbreviation shown in the "IntrusiveRock" field indicates an amagmatic area-the absence of observed intrusions. In such cases, other related fields remain blank. Intrusive rocks are briefly classified in the first field; and, in combination with the intrusion age, provide a schematic characterization of the main age groups of intrusive rocks known in the deposit areas. Five common age groupings of associated igneous rocks are outlined below:

1. Carboniferous (Mississippian) age group includes 4 deposits in the Jerritt Canyon district, Nevada, where swarms of basalt, andesitic basalt, and lamprophyre dikes are dated $320 \mathrm{Ma}$ (Phinisey and others, 1996; Hofstra and others, 1999).

2. Triassic (Indosinian) age group includes 4 deposits of the Western Qinling belt in China, where andesite porphyry, granodiorite, latite, and monzodiorite rocks are dated between the Early Mesozoic age range of 281 to $227 \mathrm{Ma}$ (Ji and others, 1998; Mao and others, 2002; Peng and others, 2010; Peters and others, 2002b; Sennitt, 2003; Wang and others, 2004).

3. Jurassic age group includes 32 deposits containing dikes and stocks related to the Yanshanian orogeny in China, and to Mesozoic magmatic events in the Great Basin province, United States. 
Stocks and plutons of diorite, granite, granodiorite, monzonite, and quartz monzonite; and dikes and sills of dacite porphyry, diabase, diabase porphyry, granite porphyry, lamprophyre, monzonite porphyry, quartz porphyry, and rhyolite are dated between 185 and $134 \mathrm{Ma}$ (peak at 160 to $150 \mathrm{Ma}$ ) (Arehart and others, 2003; Chakurian and others, 2003; Jackson and others, 2002; Liu and others, 2000; Mao and others, 2002; Mohling, 2002; Peters and others, 2002b; Ressel and Henry, 2006; Theodore and others, 2006; Wang and Zhou, 1994).

4. Cretaceous age group includes 7 deposits in the Great Basin province, where granodiorite, quartz monzonite, diorite porphyry, and quartz porphyry rocks are dated between the range of 108 to 92 Ma. (Arehart and others 2003; Cline, 2001; Groff and others, 1997; Leonardson, 2010; Marlowe and Russel, 2006; Norby and Orobona, 2002).

5. Tertiary age group includes 39 deposits in the Great Basin province (including 19 deposits where Tertiary dikes and sills are combined with Mesozoic intrusive rocks). Porphyry rocks of andesite, dacite, granite, granodiorite, mozonite, quartz porphyry, rhyodacite, rhyolite, and others are mostly constrained to the period of 41 to $35 \mathrm{Ma}$ (peak at $38 \mathrm{Ma}$ ) (Arehart and others, 2003; Hofstra and others, 1999; Ressel and others, 2000; Ressel and Henry, 2006). Though there are two younger (13 Ma) examples in island arcs and a post-mineral basalt dike of 17.6 Ma age in the Battle Mountain-Eureka Trend, Nevada (Maher and others, 1993).

\section{Age of Deposits}

Two fields of the database are related to deposit age: "DepositAgeGeologic" and "DepositAgeChronologic.” Geologic ages of deposits are usually reported as they are in the original sources; for example, Mesozoic, Indosinian, Yanshanian, and Eocene. Some geologic ages are based on observed relations of mineralized rocks to intrusive bodies. Other ages found in some sources are given without proper evidence or result from common regional geologic concepts.

Radiometric age determinations of ore and gangue minerals are rare and are sometimes reported as mismatched numbers, or, two different ages of mineralization that may not correspond to geologic ages. Limited reporting of radiometric ages from hydrothermal minerals suggest three possible epochs of sediment-hosted gold mineralization in the Great Basin province: 159-147 Ma (Jurassic) (Presnell and Parry, 1996); 109-103 Ma (Cretaceous) (Groff and others, 1997); and 42-33 Ma (Eocene) (Arehart and others, 2003; Hofstra and others, 1999; Ressel and others, 2000). These epochs approximately correlate with peaks of intrusive activity (see "Magmatic Environment” section). Age determinations of quartz, calcite, sericite, and fluid inclusions from sediment-hosted gold deposits of China suggest two main periods of mineralization: 227-210 Ma (Early Mesozoic, related to the Indosinian orogeny), and 140$125 \mathrm{Ma}$ to $41 \mathrm{Ma}$ (Cretaceous, possibly related to Yanshanian orogeny, to Tertiary) (Fu and others, 2004; Han and others, 2004; Liu and others, 2000; Lu and others, 2006; Su and others, 2009). Both main periods generally correspond to intrusion ages in the regions with this type of mineralization. These ages agree with the main Mesozoic and (or) Cenozoic magmatic events in mineralized areas. Alternative age hypotethes propose Paleozoic (Sha, 1993; Emsbo and others, 1997; Berger and Theodore, 2005) and Early Mesozoic (Gu and others, 2002; Peters and others, 2007) syn-sedimentary or diagenetic precursors to major gold accumulations in sedimentary rocks for the Great Basin province and China provinces, respectively. More age determination work is needed before sediment-hosted gold deposit ages can be determined beyond the broad regional "magmatic" dates reported in this study.

\section{Morphology, Structural Style, and Size of Deposits}

A number of fields are provided to report a deposit's shape, structural style, and size. The "DepositShapeStyle" field contains information about the shape and style of the deposit. This field also contains a short text that gives the configuration and structural control of sediment-hosted gold deposits. 
Also given is the relative importance of structural style depending on relative predominance of fault or stratigraphic (strata) controls. These features are described in the database by four fields: "BedLens," "FaultZone," "VeinStockwork," and "OreBreccia.” These four fields have two possible responses: 'yes" or 'no' (the latter indicated by an empty field). Many deposits have both faults and stratigraphic orecontrolling features.

These categories were defined and measured using detailed descriptions, maps, and reported measurements. The area ("DepositArea”) of sediment-hosted gold deposits was determined using a twodimensional projection of the deposit to a flat plane at the surface. All measurements were made using detailed maps combined with Google Earth images of deposits. The shortest dimension was measured as the distance between parallel lines that just touch the object ("DepositWidth_km”). After the short dimension was determined, the long axis was measured perpendicular to the short axis using the same criteria ("DepositLength_km"). Where there were no published estimates of the projected area of the body (footprint of the deposit), an estimate of the area was made using the standard formula for an ellipsoidal area ( $\mathrm{S}=3.14159 \mathrm{LW} / 4)$, where $\mathrm{S}$ is area in square kilometers, $\mathrm{L}$ is length in kilometers, and $\mathrm{W}$ is width in kilometers. Thickness (in meters) of the ore body is recorded in the "DepositThick_m” field.

\section{Mineralogy}

Mineralogy of all sediment-hosted gold deposits in the database is characterized by fields: “OreMinerals,” "GangueMinerals,” “GoldContainingMineral,” “GoldParticleSize_micron,” and “Alteration.” This mineralogical overview should be considered preliminary because of inconsistencies in the reporting of minerals in the literature, such as listing all minerals or only major minerals. Table 11, in the "Preliminary Analysis" section below, summarizes and organizes mineralogical data into the fields named above.

\section{Spatially Related Deposits}

The field “AssocDepositsLess10km” lists spatially-related deposits present within $10 \mathrm{~km}$ of the sediment-hosted gold deposit. In many situations, these deposits are mere occurrences and are not economical; however, a deposit type can often still be assigned. Deposit types provide information about possible associations with sediment-hosted gold deposits and their mineralizing systems. Each deposit type is identified as listed in Cox and Singer (1986) and Bliss (1992). Within 10 km, 82 spatially-related sediment-hosted gold deposits are recognized. In addition, 16 quartz-polymetallic ( $\pm \mathrm{Ag}, \mathrm{Au})$ veins, 10 $\mathrm{Pb}-\mathrm{Zn}$ replacement deposits, 7 skarn $\mathrm{Pb}-\mathrm{Zn}$-Ag-Au, and $4 \mathrm{Cu}-\mathrm{Mo}-\mathrm{Au}$ porphyry deposits composing common zoning mineralized systems are spatially associated with sediment-hosted gold deposits. These deposits belong to magmatic systems, such as the Bingham porphyry system, Utah, and Bau district, Sarawak, Malaysia, as noted by Sillitoe and Bonham (1990). Also recognized are 6 deposits of bedded barite, 6 sediment-hosted $\mathrm{Hg}( \pm \mathrm{Se}$, U, Cu) deposits, 5 Au-Ag low- and high-sulfidation epithermal deposits, 5 placer gold deposits, and 2 gold intrusion-related deposits. Besides spatial coincidence, their relations to sediment-hosted gold mineralization mainly remain unclear.

\section{References}

Related publications and unpublished materials used for the data compilation are listed in "References" that are also combined in the common "Reference list to sediment-hosted gold deposits database” (appendix 4). 


\section{Preliminary Analysis, Grade and Tonnage Models}

Grade and tonnage models of mineral deposits are useful in quantitative resource assessments and exploration planning. They help classify known deposits in a region, delineate permissive areas for specific deposit types, and provide information about the potential value of undiscovered deposits in the assessment area. Construction of grade and tonnage models involves multiple steps. The first step is to identify a group of well-explored deposits that are believed to belong to the mineral deposit type being modeled. "Well-explored" here means drilled in three dimensions in order to outline the deposit at the lowest cutoff, including inferred resource category (Singer and Menzie, 2010). After deposits are identified, data from each are compiled. These data consist of average grades of each metal or mineral commodity of possible economic interest and tonnages based on the total production, reserves, and resources at the lowest available cutoff grade. In our database, we list deposits with recorded tonnages in the "TotalTonnage" field. Relations among gold grades and ore tonnage are important for predicting resources, as well as expanding our understanding of how deposits form, and for their effect on our assumptions about resource availability.

Many grade and tonnage models are presented in a graphical format to display data visually and to compare deposit types. Grade and tonnage plots show the cumulative proportion of deposits versus the tonnage or grade of the deposits. In each plot, individual symbols represent deposits, and intercepts for the 90th, 50th, and 10th percentiles are shown. Percentiles of grades that contain unreported values, such as silver, are based on observed distributions. Silver grades in sediment-hosted gold deposits are not of economic interest; therefore, unreported silver grades are not considered to be lower than reported silver grades. Reported silver grades might be a reasonable model for unreported grades in this deposit type. Frequency distributions of gold and silver grades and tonnages from the well-explored deposits can be used as models for grades and tonnages of undiscovered deposits.

In this section, we present three new grade-tonnage models for sediment-hosted gold deposits. The first model is a general grade-tonnage model for all sediment-hosted gold deposits as a single type. Gold deposits were ascribed to this type according to their definitions in original sources supported by geological and mineralogical data. The next two models are subtypes of the general model called the Carlin and Chinese grade-tonnage models. The Carlin and Chinese models have geological differences that may be applicable in some mineral resource assessments. Grade and tonnage data statistics are plotted and presented for each model.

\section{General Grade and Tonnage Model}

Grade and tonnage data in this study are compiled from sediment-hosted gold deposits in the United States, China, Indonesia, Iran, and Malaysia that are thought to be the same type of gold deposit. First, statistical tests of the grade and tonnage data are run to see if these deposits can be treated as a single population. Frequencies for the average gold and silver grades and total tonnage for the general sediment-hosted gold grade and tonnage model are plotted in figures 4-6 and are summarized in table 5. The median tonnage is 5.7 Mt for 118 deposits. Based on the methods of Singer and Menzie (2010), the tonnages in this group are consistent with a lognormal distribution at the 1-percent level of confidence, which allows these deposits to be grouped as a single population. The median gold grade is $2.9 \mathrm{~g} / \mathrm{t} \mathrm{Au}$. Average gold grades are not different than a lognormal distribution at the 1 percent level, which further supports a single population for this group. Further tests show that removing extremely high and low gold grades in this data set has no affect on the distribution of gold grades. Reported for the first time in this study are silver grades for which distribution is also lognormal at the 1-percent level of confidence. Less than 30 percent of the 118 deposits with reported silver grades gives $0.65 \mathrm{~g} / \mathrm{t}$ of silver at the 10th percentile. Therefore, this general grade and tonnage model for sediment-hosted gold deposits may be applicable for use in regional assessments. 


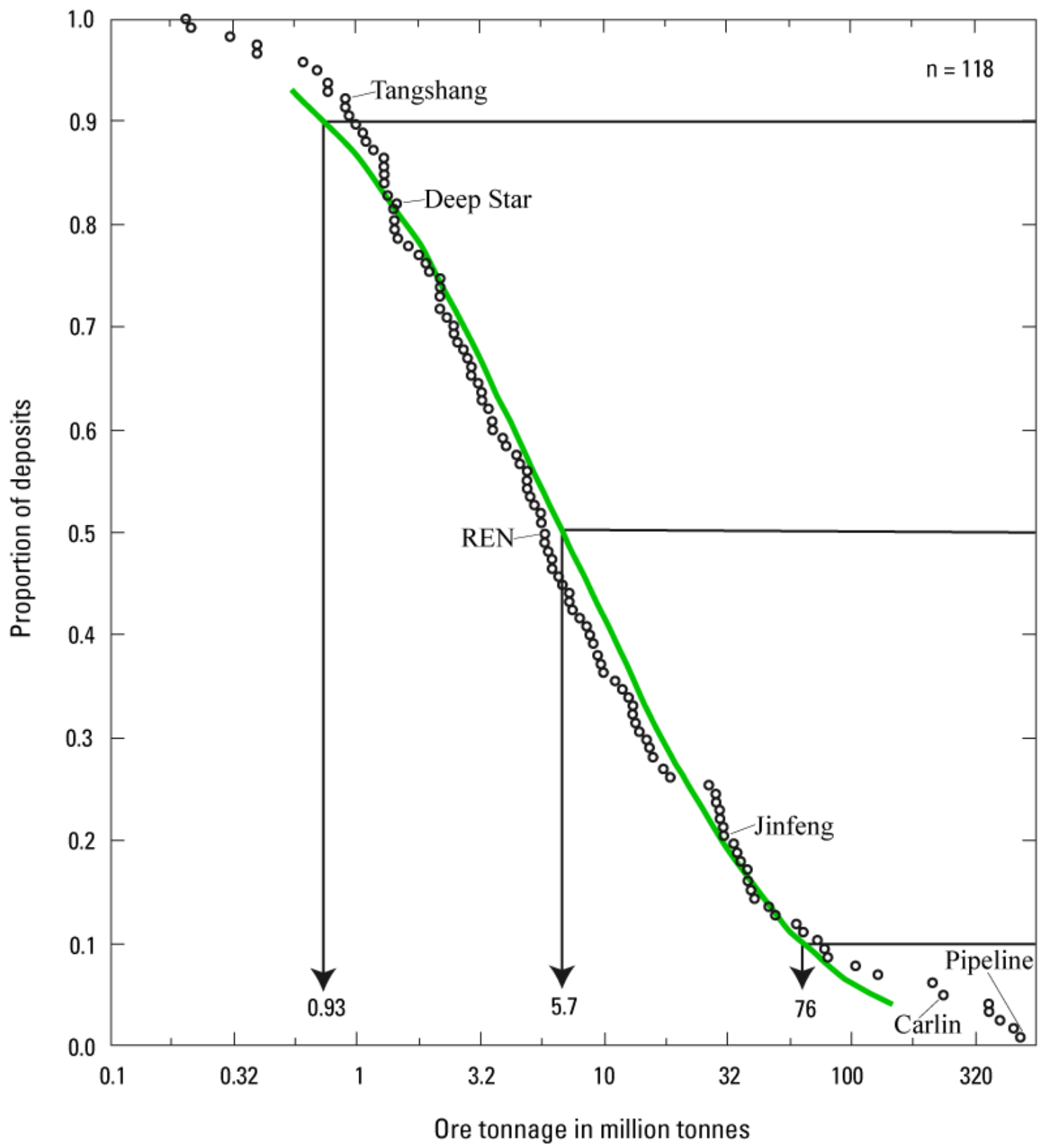

Figure 4. Cumulative frequency plot of ore tonnages and tonnage model for the general sediment-hosted gold deposit type. Each circle represents an individual deposit and green line shows tonnage model curve. Intercepts for the 90th, 50th, and 10th percentiles of the observed distribution are provided. Some deposits are named to provide orientation. 


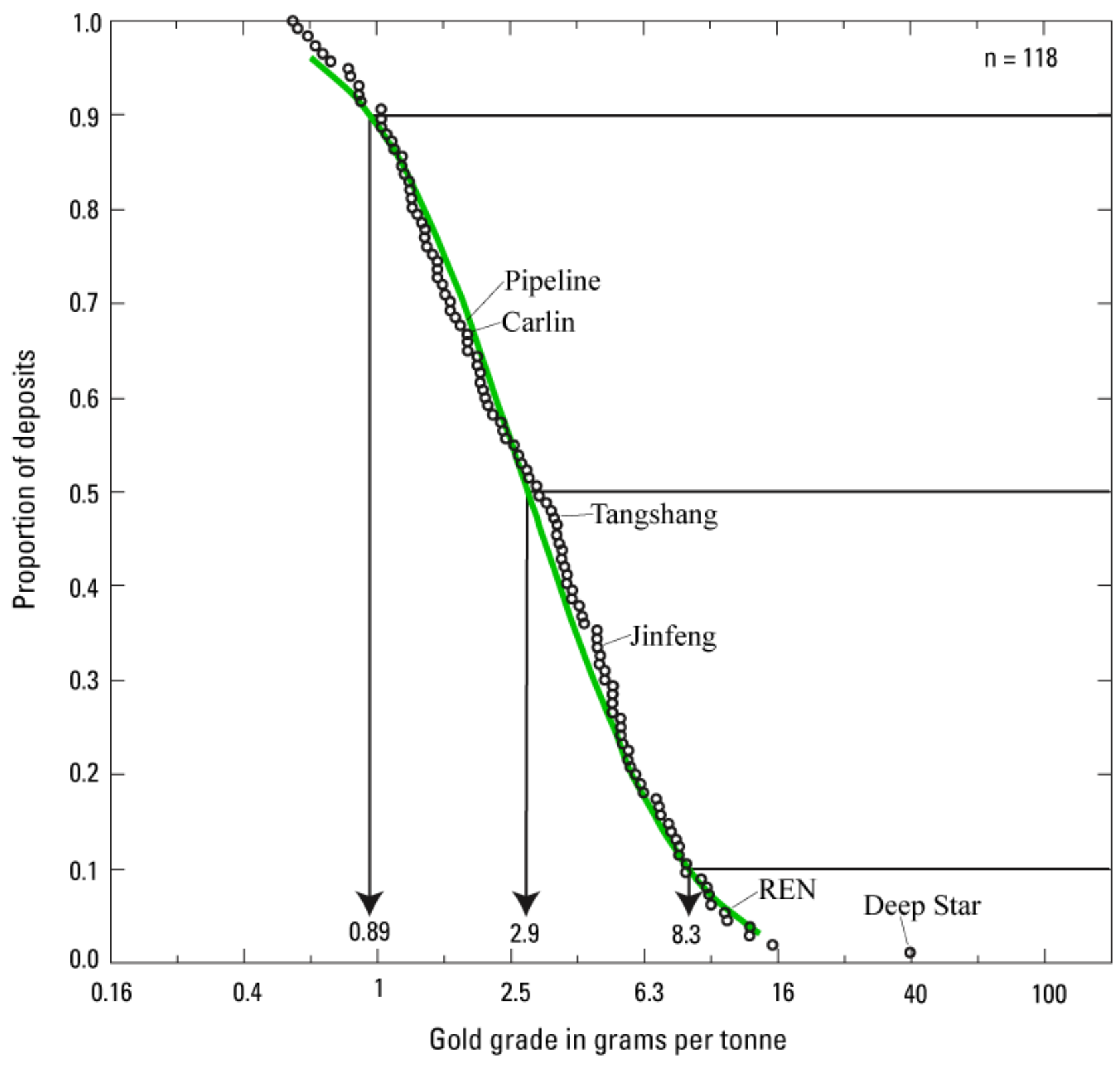

Figure 5. Cumulative frequency plot of gold grades and gold grade model for the general sediment-hosted gold deposit type. Each circle represents an individual deposit and the green line shows gold grade model curve. Intercepts for the 90th, 50th, and 10th percentiles of the observed distribution are provided. Some deposits are named to provide orientation. 


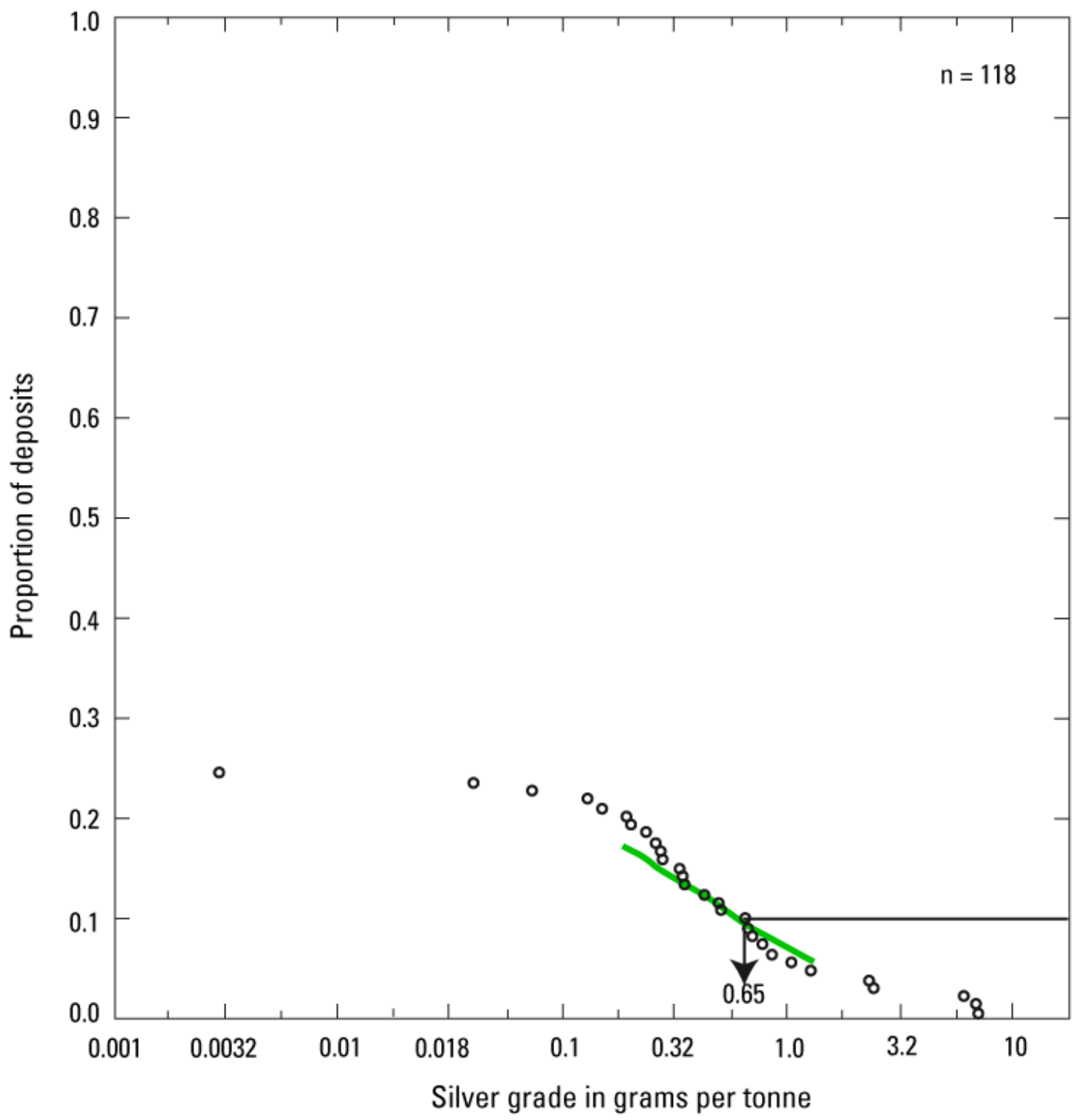

Figure 6. Cumulative frequency plot of silver grades and silver grade model for the general sediment-hosted gold deposit type. Each circle represents an individual deposit and the green line shows silver grade model curve. Intercept for the 10th percentile of the observed distribution is provided. 
Table 5. Statistical summary of grade and tonnage models of sediment-hosted gold deposits.

[Tonnage reported in millions of metric tons; gold and silver grades reported in grams per tonne $(\mathrm{g} / \mathrm{t})$.]

\begin{tabular}{|c|c|c|c|c|c|}
\hline $\begin{array}{l}\text { Deposit model type } \\
\text { and subtype }\end{array}$ & $\begin{array}{l}\text { Number } \\
\text { deposits }\end{array}$ & Unit of measurement & $\begin{array}{l}10^{\text {th }} \text { percentile } \\
\text { of deposits }\end{array}$ & $\begin{array}{l}50^{\text {th }} \text { percentile } \\
\text { of deposits }\end{array}$ & $\begin{array}{l}\text { 90th percentile } \\
\text { of deposits }\end{array}$ \\
\hline \multirow{3}{*}{$\begin{array}{l}\text { General sediment-hosted } \\
\text { gold deposit type }\end{array}$} & \multirow[t]{3}{*}{118} & Million tonnes & 76 & 5.7 & 0.93 \\
\hline & & $\mathrm{Au}, \mathrm{g} / \mathrm{t}$ & 8.3 & \multirow[t]{2}{*}{2.9} & \multirow[t]{2}{*}{0.89} \\
\hline & & Ag, g/t & 0.65 & & \\
\hline Carlin subtype, United & \multirow{3}{*}{88} & Million tonnes & 110 & 7.1 & 0.94 \\
\hline States, Indonesia, Iran, & & $\mathrm{Au}, \mathrm{g} / \mathrm{t}$ & 8.4 & \multirow[t]{2}{*}{2.0} & \multirow[t]{2}{*}{0.83} \\
\hline Malaysia & & $\mathrm{Ag}, \mathrm{g} / \mathrm{t}$ & 0.78 & & \\
\hline \multirow[t]{2}{*}{ Chinese subtype, China } & \multirow[t]{2}{*}{30} & Million tonnes & 16 & 3.9 & 0.92 \\
\hline & & $\mathrm{Au}, \mathrm{g} / \mathrm{t}$ & 6.8 & 4.6 & 2.3 \\
\hline
\end{tabular}

In the general model, geologic data groupings (such as tectonic setting or magmatic environments) suggest that some geologic features may affect the size and gold content (tonnes of gold) of sediment-hosted gold deposits. Statistical presentation of important geological features supports the general grade and tonnage model. However, because of the small sample sizes and unequal variances of some of the geologic groups, the following analyses are preliminary.

\section{Tectonic Settings}

Tectonic settings for sediment-hosted gold deposits in this study include cratons or fold belts in North America or China. Each is characterized quantitatively and briefly described below. In all tectonic settings, we test for differences in tonnage, gold grades, and contained gold. We found that sample set sizes in groups are similar with the exception of those for gold grades. Therefore, ANOVA (analysis of variance) was used to test the variances of tonnage and contained gold and the nonparametric Welsh's test was used to test the variance of gold grades among the four tectonic setting groups. Results of this analysis are shown in table 6 and figure 7.

Table 6. Tonnage, gold grades, and contained gold of sediment-hosted gold deposits of different tectonic settings and subsettings.

$\left[{ }^{1}\right.$ General, total numeric characteristics of all deposits in the data set. ${ }^{2}$ Tonnage reported in metric tons. ${ }^{3}$ Significant differences between median values of the four groups at the $1 \%$ level or less are indicated in bold.]

\begin{tabular}{|c|c|c|c|c|c|c|c|c|}
\hline \multirow[t]{2}{*}{ Tectonic setting } & \multirow{2}{*}{$\begin{array}{l}\text { Number } \\
\text { deposits }\end{array}$} & \multicolumn{3}{|c|}{ Total ore tonnage $^{2}$} & \multirow{2}{*}{$\begin{array}{c}\text { Median } \mathrm{Au} \\
\text { grade, g/t }\end{array}$} & \multicolumn{3}{|c|}{ Total contained gold } \\
\hline & & $\begin{array}{c}\text { Ore, } \\
\text { million } \\
\text { tonnes }\end{array}$ & $\%$ & $\begin{array}{l}\text { Median, million } \\
\text { tonnes }\end{array}$ & & $\begin{array}{c}\mathrm{Au} \\
\text { tonnes }\end{array}$ & $\%$ & $\begin{array}{l}\text { Median, } \\
\text { Au tonnes }\end{array}$ \\
\hline Platform & 66 & 2,538 & 60 & 5.2 & 4.33 & 5,891 & 61 & 26 \\
\hline $\begin{array}{l}\text { Foreland } \\
\text { basin }\end{array}$ & 22 & 242 & 6 & $3.1^{3}$ & 1.27 & 310 & 3 & 4 \\
\hline $\begin{array}{l}\text { Imbricate } \\
\text { structure }\end{array}$ & 13 & 1,173 & 28 & 39.0 & 1.85 & 2,503 & 26 & 56 \\
\hline Fold belt & 17 & 258 & 6 & 6.6 & 3.80 & 927 & 10 & 21 \\
\hline General $^{1}$ & 118 & 4,211 & 100 & 5.7 & 2.9 & 9,631 & 100 & 19 \\
\hline
\end{tabular}



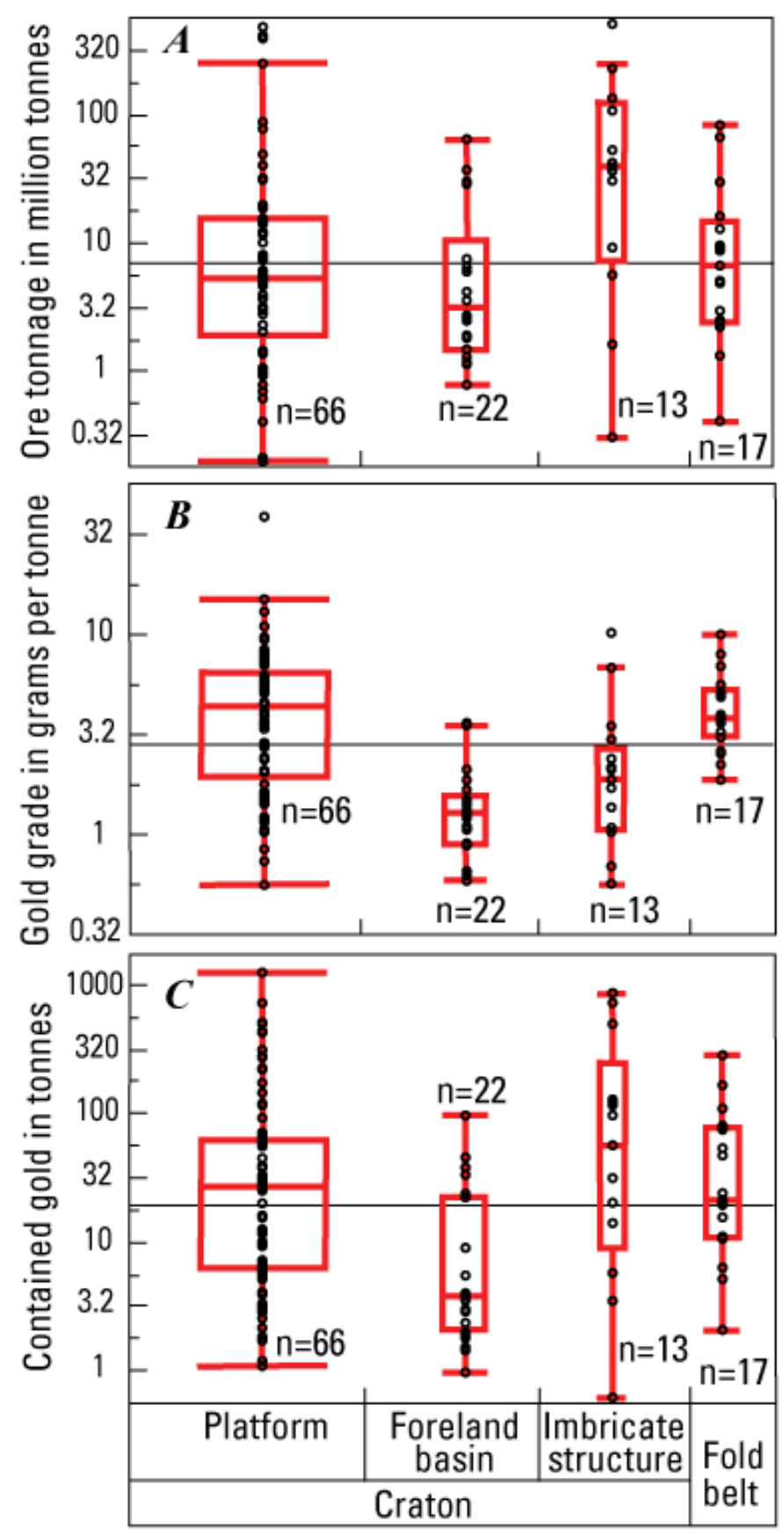

Figure 7. Box plots of sediment-hosted gold deposits of different tectonic settings. $A$, Tonnage plot, $B$, Gold grade plot, $C$, Contained gold plot. Circles are individual deposits, median value is the center line of box, 25th and 75th quartiles are top and bottom of box, the upper line is the $100 \%$ percentile, the lower line is the $0 \%$ percentile, and the line across the plot is the grand mean. Box plot width is proportional to sample size.

The craton tectonic group contains 101 deposits that are located within the rifted western margin of the North American craton (Great Basin province) and southwestern margin of the South China craton (Dian-Qian-Gui province) that underwent superimposed multistage tectonic and magmatic events in the Late Paleozoic, Mesozoic and Cenozoic (Cline and others, 2005; Emsbo and others, 2006; Hofstra and Cline, 2000; Hofstra and Christensen, 2002; Hu and others, 2002; Zaw and others, 2007). This group is divided further into three subsettings: platform, foreland basin, and imbricate structure. There are 66 deposits hosted in carbonate and carbonate-clastic sedimentary sequences of the platform and 
continental slope (Armstrong and others, 1997) at the marginal rifted parts of North American and South China cratons. In the Great Basin province, deposits of this group are mostly confined to the east assemblage (Roberts, 1966) of the RMT (Roberts Mountain thrust) autochthonous lower plate. This is the most common subsetting for sediment-hosted gold deposits and represents 60 percent of the total ore tonnages and 61 percent of the total contained gold in sediment-hosted gold deposits (table 6). Gold grade is significantly higher, with a median of $4.33 \mathrm{~g} / \mathrm{t} \mathrm{Au}$, than that found in the two other groups of cratonic settings in table 6.

The Great Basin province contains 22 deposits hosted in siliciclastic and clastic-carbonate sequences of foreland basin related to the Late Devonian-Mississippian Antler orogeny and to the evolution of the regional Roberts Mountains thrust (Poole and others, 1977; Roberts, R.J., 1966; Trexler and others, 1991). This tectonic setting represents 6 percent of the total ore tonnages and 3 percent of the total contained gold in sediment-hosted gold deposits (table 6). The deposits are characterized by lower tonnage and lower median gold grade at $1.27 \mathrm{~g} / \mathrm{t}$ Au. Perhaps this can be related to a change of tectonic setting, now predominantly consisting of siliciclastic lithology of mineralized rocks of relatively younger Late Paleozoic age (Maher, 1997; Berger and Theodore, 2005).

At least 13 deposits in the Great Basin province are hosted in complex tectonic settings of imbricate thrust structures at craton margins (Crafford, 2000; Leonardson, 2010; Nemitz, 2005). These zones are often confined to shear zones and contain stacked carbonate, chert, siliciclastic, and basaltic sequences of autochthonous and allochthonous plates. Economic gold mineralization is found in different strata and plates (including the Roberts Mountain thrust upper plate composed of the western assemblage) that contrast in composition and age. This small group represents 28 percent of the total ore tonnages and 26 percent of the total contained gold in sediment-hosted gold deposits (table 6), and shows an extraordinarily high median ore tonnage of $39 \mathrm{Mt}$ and median contained gold of 56 tonnes.

The next group of tectonic settings contains fold belts and magmatic arcs (table 6). This group includes 17 deposits with 6 percent of the total ore tonnages and 10 percent of the total contained gold in sediment-hosted gold deposits. With limited reported data, it is not possible to subdivide this group into different tectonic subsettings. This combined group includes: the Qinling fold belt (Mao and others, 2002) and the Yangtze fold belt (Peters and others, 2002c) in China; the Zagros fold belt (Asadi and others, 2000); Central Kalimantan magmatic arc with the Mesozoic sedimentary sequence of the socalled Sundaland continent (Christensen and others, 1996; Wolfenden, 1965); and Neogene North Sulawesi volcanic island arc with the Miocene carbonate-clastic Ratatotok basin (Garwin and others, 1995). The carbonate-siliciclastic composition is typical to ore-bearing sedimentary sequences that range tectonically from Precambrian basement terranes and strongly folded complexes to overlapping local depressions.

\section{Magmatic Environment}

Numerous bodies of intrusive rocks are hydrothermally altered and contain gold mineralization. Genetic relations of sediment-hosted gold with intrusive rocks of different age and composition are disputable; however, many researchers consider the widespread Jurassic and Tertiary intrusive groups to be the source for gold found in sediment-hosted gold deposits (Arehart, 1996; Bettles, 2002; Cline and others, 2005; Hu and others, 2002; Mao and others, 2002, Peters and others, 2002a, 2002b; Ressel and Henry, 2006; Ressel and others, 2000). As described above, radiometric age determinations of ore and gangue minerals from sediment-hosted gold deposits correspond to main regional Mesozoic and (or) Cenozoic magmatic events in mineralized areas.

Statistical tests were undertaken to estimate the importance of intrusive rocks and the extent of their influence on sediment-hosted gold deposits. The entire population of deposits was divided into three groups with respect to intrusive rock presence: (1) amagmatic environment, meaning that igneous rocks are not present on the surface of the deposit area and are not exposed in open pit and underground 
workings or in drill-holes; (2) magmatic environment, that is marked by presence of dikes and sills; and (or) (3) stocks and plutons, located within the area of the deposit or immediate vicinity. The last group of deposits with stocks and plutons also are found with numerous dikes and are indicated with ' \pm dike'.

In the three magmatic environment groups, we test for differences in tonnage, gold grades, and contained gold. The results are described below and shown in figure 8 and in table 7 . For tonnages, the nonparametric Welsh's test was used to test the variance of the $\log _{10}$ of tonnages among the three magmatic environment groups (fig. $8 A$ ). The $\log _{10}$ of tonnages are significantly different at the 1 percent level of confidence; however, because this is a non-parametric result, we cannot interpret the differences in deposit size geologically.
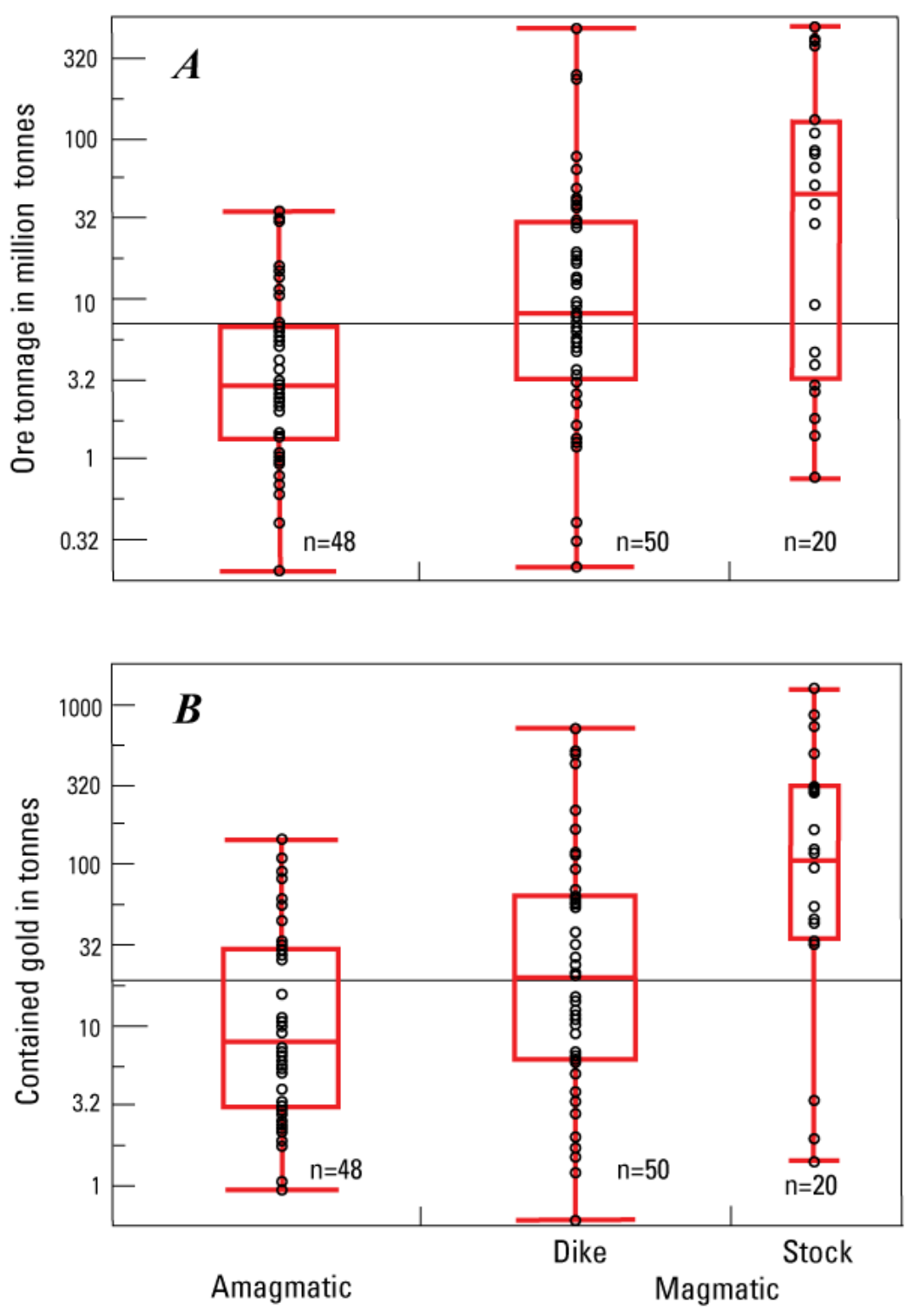

Environment

Figure 8. Box plots of sediment-hosted gold deposits located in amagmatic and magmatic (dike and stock) environments: $A$, Tonnages, $B$, Contained gold. Circles are individual deposit tonnages, median value is the center line of box, 25th and 75th quartiles are top and bottom of box, the upper line is the $100 \%$ percentile, the lower line is the $0 \%$ percentile, and the line across the plot is the grand mean. Box plot width is proportional to sample size. 
Table 7. Tonnage and grades of sediment-hosted gold deposits separated into amagmatic and magmatic (dike, stock) environments.

$\left[{ }^{1}\right.$ General, total numeric characteristics of all deposits in the data set. ${ }^{2}$ Tonnage reported in metric tons. ${ }^{3}$ Significant differences between median values of the three groups at the $1 \%$ level or less are indicated in bold.]

\begin{tabular}{|c|c|c|c|c|c|c|c|c|}
\hline \multirow[t]{2}{*}{ Environment } & \multirow{2}{*}{$\begin{array}{l}\text { Number of } \\
\text { deposits }\end{array}$} & \multicolumn{3}{|c|}{ Total ore tonnage $^{2}$} & \multirow{2}{*}{$\begin{array}{c}\text { Median } \\
\text { Au grade, } \\
\text { g/t }\end{array}$} & \multicolumn{3}{|c|}{ Total contained gold } \\
\hline & & $\begin{array}{c}\text { Ore, } \\
\text { million } \\
\text { tonnes }\end{array}$ & $\%$ & $\begin{array}{l}\text { Median, } \\
\text { million } \\
\text { tonnes }\end{array}$ & & Au tonnes & $\%$ & $\begin{array}{l}\text { Median, } \\
\text { Au tonnes }\end{array}$ \\
\hline Amagmatic & 48 & 311 & 7 & $2.8^{3}$ & 3.55 & 1,020 & 11 & 7.8 \\
\hline Magmatic: & & & & & & & & \\
\hline Dike presence & 50 & $1,62 €$ & 39 & 7.9 & 2.34 & 3,739 & 39 & 19.6 \\
\hline Stock presence & 20 & 2,274 & 54 & 44.5 & 2.74 & 4,872 & 50 & 104.0 \\
\hline General $^{1}$ & 118 & 4,211 & 100 & 5.7 & 2.9 & 9,631 & 100 & 19 \\
\hline
\end{tabular}

ANOVA (analysis of variance) tests show that the $\log _{10}$ of gold grades in the three magmatic environment groups are not significantly different.

The $\log _{10}$ of contained gold are significantly different using ANOVA test for variation in the three magmatic environment groups (fig. 8B). These differences indicate that the gold contents of sediment-hosted gold deposits increase spatially from distal (amagmatic) to peripheral (dike and sill) and finally to proximal (stock, pluton) parts of magmatic systems. Statistical analysis of current published data gathered in the database, suggests that magmatic manifestations (such as dikes and stocks), exposed on the surface or in underground workings in areas of sediment-hosted gold deposits, correlate positively with ore tonnages and gold content. Thus, it is important to consider the presence of intrusions while evaluating the magnitude of prospective sediment-hosted gold mineralization. Please note that this study does not determine whether this result is an artifact of better reporting near the larger deposits or a genetic effect of the igneous rocks. Comparable results have been observed in the gradetonnage modeling of sediment-hosted polymetallic deposits, in which it was discovered that the frequency of the presence of gold and gold grades are significantly higher in deposits with spatially associated intrusions (Singer and others, 2009).

Concluding, this observation suggests that both explorationists and those involved in assessments, where these deposit types may be present, need to consider the presence of intrusions as an important feature for the evaluation of the magnitude of prospective sediment-hosted gold mineralization.

Additionally, silver grades were reported in the production data of 29 deposits, 24 of them (83 percent) pertain to the magmatic environment. However, the lack of reported silver grades did not allow for further analyses among the groups.

\section{Structural Styles}

Next we examine the role of structural styles on sediment-hosted gold deposits shown in the "DepositShapeStyle" field partially corresponding to the "StructuralSetting" field of the database. In order to investigate this, deposits have been classified in one of three types: (1) fault-controlled; (2) fault- and strata-controlled; and (3) strata-controlled. The basis of this three-part classification scheme was proposed in different terms by Berger (1986), Berger and Bagby (1991), Christensen (1993), and Jory (2002). Deposits of the fault-controlled style consist mainly of steeply dipping mineralized zones of micron-sized disseminated gold with subordinate vein, stockwork, and breccia bodies commonly located in faults along contacts of dikes and sills. As a rule, mineralization is controlled by high-angle normal faults and in some deposits by strike-slip and reverse faults, and their associated shear zones. The second style, fault- and strata-controlled, includes deposits with a combination of high angle fault-controlled 
and stratabound mineralized rocks extending along bedding of favorable sedimentary rocks. The third group of strata-controlled deposits is dominated with stratabound and stratiform layered mineralized rocks. Some deposits also are complicated by thrusts and bedding-plane faults.

Summary statistics of the three main structural styles of sediment-hosted gold deposits are tabulated in table 8 . Statistical analysis suggests that no one of the variables found to be significantly different between mean values of grade and tonnage of the all three styles. The lack of statistical differences between fault- and strata-controlled end-members of the structural style classification suggests that these factors are not crucial in the control of deposit grade or tonnage.

Table 8. Tonnage and grades of sediment-hosted gold deposits of different structural styles.

[ ${ }^{1}$ General, total numeric characteristics of all deposits in the data set. ${ }^{2}$ Tonnage reported in metric tons.]

\begin{tabular}{|c|c|c|c|c|c|c|c|c|}
\hline \multirow{2}{*}{$\begin{array}{c}\text { Structural style of } \\
\text { deposit }\end{array}$} & \multirow{2}{*}{$\begin{array}{l}\text { Number } \\
\text { deposits }\end{array}$} & \multicolumn{3}{|c|}{ Total ore tonnage $^{2}$} & \multirow{2}{*}{$\begin{array}{l}\text { Median Au } \\
\text { grade, g/t }\end{array}$} & \multicolumn{3}{|c|}{ Total contained gold } \\
\hline & & $\begin{array}{l}\text { Ore, } \\
\text { million } \\
\text { tonnes }\end{array}$ & $\%$ & $\begin{array}{l}\text { Median, } \\
\text { million } \\
\text { tonnes }\end{array}$ & & $\begin{array}{l}\mathrm{Au} \\
\text { tonnes }\end{array}$ & $\%$ & $\begin{array}{l}\text { an, } \\
\text { nes }\end{array}$ \\
\hline Fault-controlled & 29 & 1,336 & 32 & 6.0 & 2.14 & 3,266 & 34 & 23.4 \\
\hline \multicolumn{9}{|l|}{$\begin{array}{l}\text { Fault- and strata- } \\
\text { controlled }\end{array}$} \\
\hline & 26 & 821 & 19 & 6.0 & 2.66 & 1,319 & 14 & 13.6 \\
\hline \multicolumn{9}{|l|}{ Strata- controlled } \\
\hline & 63 & 2,054 & 49 & 5.3 & 3.46 & 5,046 & 52 & 19.0 \\
\hline General $^{1}$ & 118 & 4,211 & 100 & 5.7 & 2.9 & 9,631 & 100 & 19.0 \\
\hline
\end{tabular}

Combination of structural style and magmatic environment

A comparison between deposit structural style and presence and morphology of intrusive rocks (table 9) reveal a notable and systematic increase of the number of fault-controlled deposits from the 'Amagmatic' category (31 percent of all deposit styles in this environment) to the 'Dike and sill' category (52 percent) and finally to the 'Stock \pm dike' category (70 percent). The opposite trend is present in strata-controlled deposits (table 9). For example, in an amagmatic geologic setting, 69 percent of all deposits are strata-controlled; in areas with dikes and sills, 47 percent are strata-controlled; and where stocks and dikes are prevalent, only 30 percent are strata-controlled. Both results reinforce the observation that faults and other deformations become more extensive in the vicinity of intrusions thereby affecting the distributions and styles of sediment-hosted gold deposits.

Table 9. Proportion of different structural style deposits in areas with different styles (or lack) of intrusive rock.

[Count, number of deposits; \%, percent of deposits.]

\begin{tabular}{|c|c|c|c|c|c|c|}
\hline \multirow[t]{3}{*}{ Structural style of deposit } & \multirow{2}{*}{\multicolumn{2}{|c|}{ Amagmatic environment }} & \multicolumn{4}{|c|}{ Magmatic environment } \\
\hline & & & \multicolumn{2}{|c|}{ Dike+Sill } & \multicolumn{2}{|c|}{ Stock ( \pm dike) } \\
\hline & Count & $\%$ & Count & $\%$ & Count & $\%$ \\
\hline Fault-controlled & 7 & 15 & 13 & 26 & 9 & 45 \\
\hline Fault- and Strata-controlled & 8 & 16 & 13 & 26 & 5 & 25 \\
\hline Strata-controlled & 33 & 69 & 24 & 48 & 6 & 30 \\
\hline Total & 48 & 100 & 50 & 100 & 20 & 100 \\
\hline
\end{tabular}


To statistically estimate a collective effect of structural and magmatic (intrusion) factors on tonnages and gold grades of sediment-hosted gold deposit, compiled data were regrouped into four combinations indicated by abbreviations: FA, SA, FM, and SM. F means combined fault-controlled deposits (for example, fault-controlled and fault- and strata-controlled deposits) that are grouped as one subset; S means strata-shaped deposits (stratabound and stratiform); A, amagmatic environment; and M, magmatic environment including the presence of both dikes and stocks in a deposit area (see illustrations in fig. 9). These four combinations of the structural style and magmatic environment were analyzed using Oneway analysis of variance (table 10, fig. 10). $\log _{10}$ of tonnages of deposits in both structural styles in the magmatic environments are significantly larger than those in amagmatic environments (table 10, fig. 10A). However gold grades are not statistically different among the four groups. $\log _{10}$ medians of contained gold shows the same differences as the tonnages (table 10, fig. $10 B$,). These results support the suggestion that magmatic environments are critical for the intensity of mineralization regardless of structural styles of deposits. Independently of the genetic interpretations, this conclusion is important in the regional assessment of prospective areas for sediment-hosted gold deposits.

Table 10. Tonnage and gold grade in four observed combinations of structural style and magmatic environment of sediment-hosted gold deposits

$\left[{ }^{1}\right.$ General, total numeric characteristics of all deposits in the data set. ${ }^{2}$ Tonnage reported in metric tons. ${ }^{3}$ Significant differences between median values of the four groups at the $1 \%$ level or less are indicated in bold.]

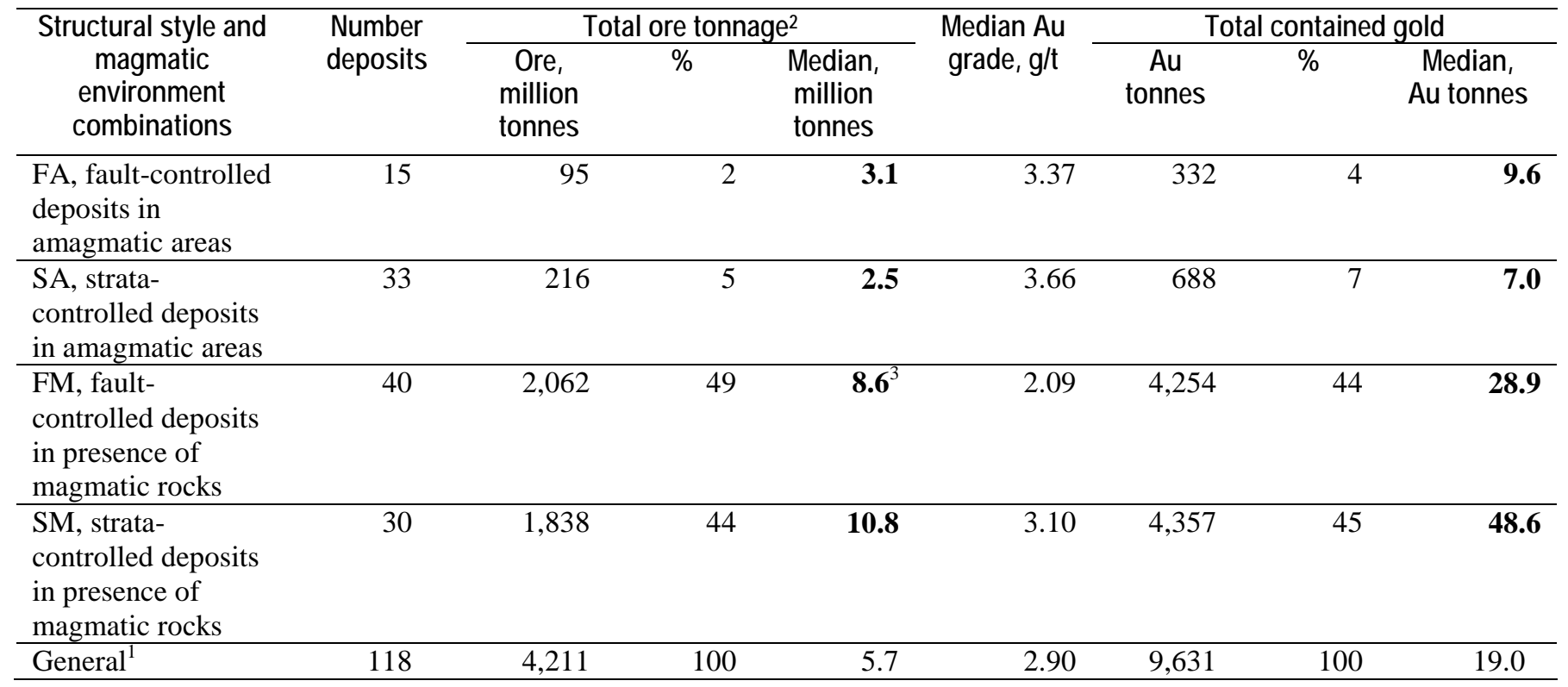




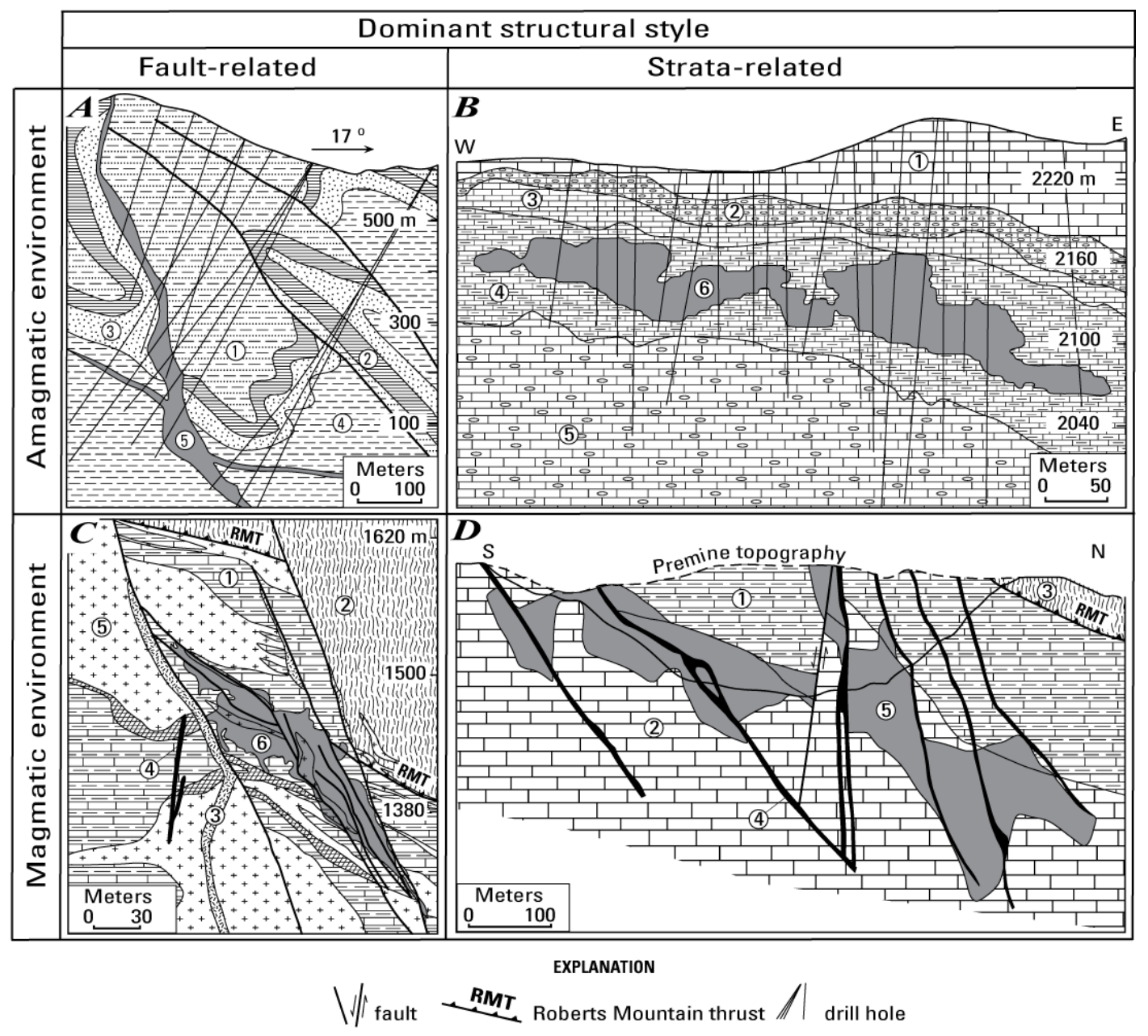

Figure 9. Cross-sections of selected sediment-hosted gold deposits illustrating how ore bodies relate to dominant structural styles in two different magmatic environments: A, Jinfeng (Lannigou) deposit, Guizhou, China (faultcontrolled deposit in an amagmatic environment); 1-4, Middle Triassic sequence: 1 , sandstone and mudstone, Bianyang Formation (Fm.); 2, mudstone, nodular limestone, Niluo Fm.; 3, sandstone, Xuman Fm.; 4, mudstone, Xuman Fm.; 5, orebody averaging $6.5 \mathrm{~g} / \mathrm{t}$ Au (modified from Chen and others, 2011). B, Starvation Canyon deposit, Jerritt Canyon district, Nevada, strata-controlled deposit in amagmatic environment; 1 , calcareous siltstone and silty limestone, Silurian and Lower Devonian Roberts Mountains Fm.; 2-5, Late Ordovician and Early Silurian Hanson Creek Fm.: 2, interbedded chert and carbonaceous limestone (Unit 1); 3, laminated and massive limestone (Unit 2); 4, argillaceous and micritic limestone (Unit 3); 5, carbonaceous pyritic limestone (Unit 4); 6, orebody averaging 9.7 g/t Au (modified from Yukon-Nevada Gold Corp., 2012). C, Deep Star deposit, northern Carlin Trend, Nevada, fault-controlled deposit in magmatic environment; 1, calc-silicate rocks and marble (contact metamorphosed silty limestone of Devonian Popovich Fm.); 2, hornfels (contact metamorphosed siliceous mudstone of Ordovician Vinini Fm., upper plate of RMT); 3, rhyolite dike, 38 Ma; 4, lamprophyre dike, 158-156 Ma; 5, granodiorite and quartz diorite of Goldstrike stock, $158 \mathrm{Ma}$; 6, orebody averaging $9.7 \mathrm{~g} / \mathrm{t} \mathrm{Au}$ (modified from Clode and others, 2002). D, Carlin deposit, northern Carlin Trend, Nevada, strata-related deposit in magmatic environment: 1, silty limestone, Devonian Popovich Fm.; 2, silty limestone and dolomitic siltstone, Silurian and Lower Devonian Roberts Mountains Fm.; 3, chert, mudstone, siliceous siltstone, Ordovician Vinini Fm., upper plate of RMT; 4, lamprophyre dike, Jurassic-Cretaceous (?); 5, orebody averaging $1.66 \mathrm{~g} / \mathrm{t} \mathrm{Au}$ (modified from Myers, 1993; Chakurian and others, 2003). 

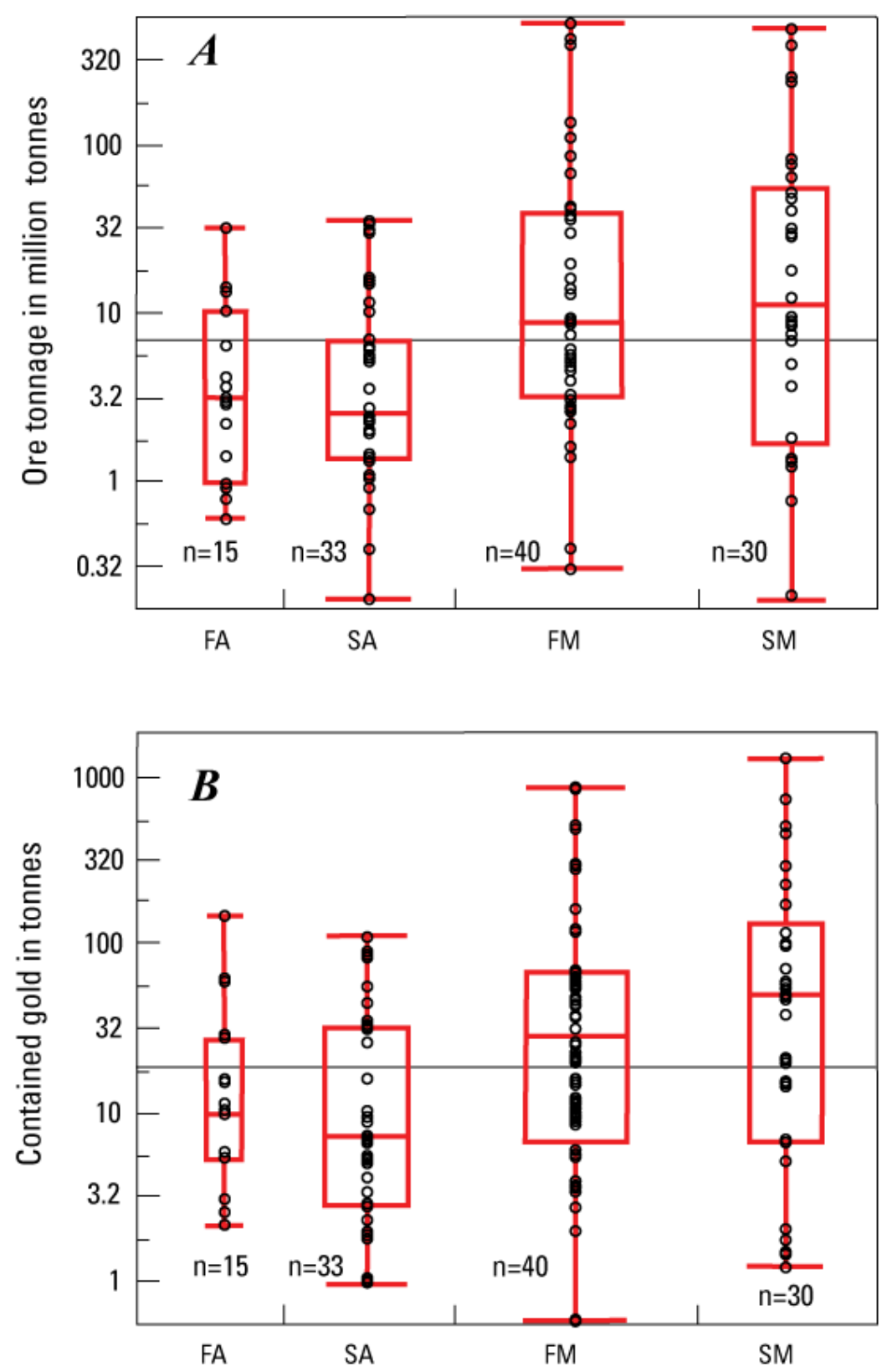

Structural style and magmatic environment combinations

Figure 10. Box-plots of ore tonnages and contained gold of sediment-hosted gold deposits by four observed combinations of structural style and magmatic environment: FA, fault-controlled deposits in amagmatic areas; $\mathrm{SA}$, strata-controlled deposits in amagmatic areas; $\mathrm{FM}$, fault-controlled deposits in presence of magmatic rocks; $\mathrm{SM}$, strata-controlled deposits in presence of magmatic rocks. $A$, Ore tonnages, $B$, Contained gold. 


\section{Ore-Bearing Unit Thickness}

There are 88 deposits with ore-bearing unit thicknesses reported with tonnage and gold grades. Statistical tests revealed no significant correlations between deposit tonnages or grades and the orebearing unit thicknesses.

\section{Deposit Area and Thickness}

Statistical tests for normal distribution of tonnages between deposit tonnage and deposit area of sediment-hosted gold deposits cannot be performed because the tests yield a bimodal distribution and are rejected. This may be due to magmatic and structural styles of deposits (see below) and (or) to mining methods.

Statistical tests show a correlation between deposit tonnages and deposit thicknesses (fig. 11) with a correlation coefficient $r=0.47$ significant at the 1 percent level. The linear fit regression equation (with rounded numbers) is $y=-0.64+0.93 x$, where ' $y$ ' is $\log _{10}$ of Mt, and ' $x$ ' is $\log _{10}$ of total orebody thickness. The equation may have some practical applications to local assessments of prospective sediment-hosted gold mineralized areas. Separate plots of the United States and China deposits show strong positive correlations between tonnages and areas and thicknesses of the former group. However, a lack of the significant correlations in the China group cannot be explained on the basis of the compiled data.

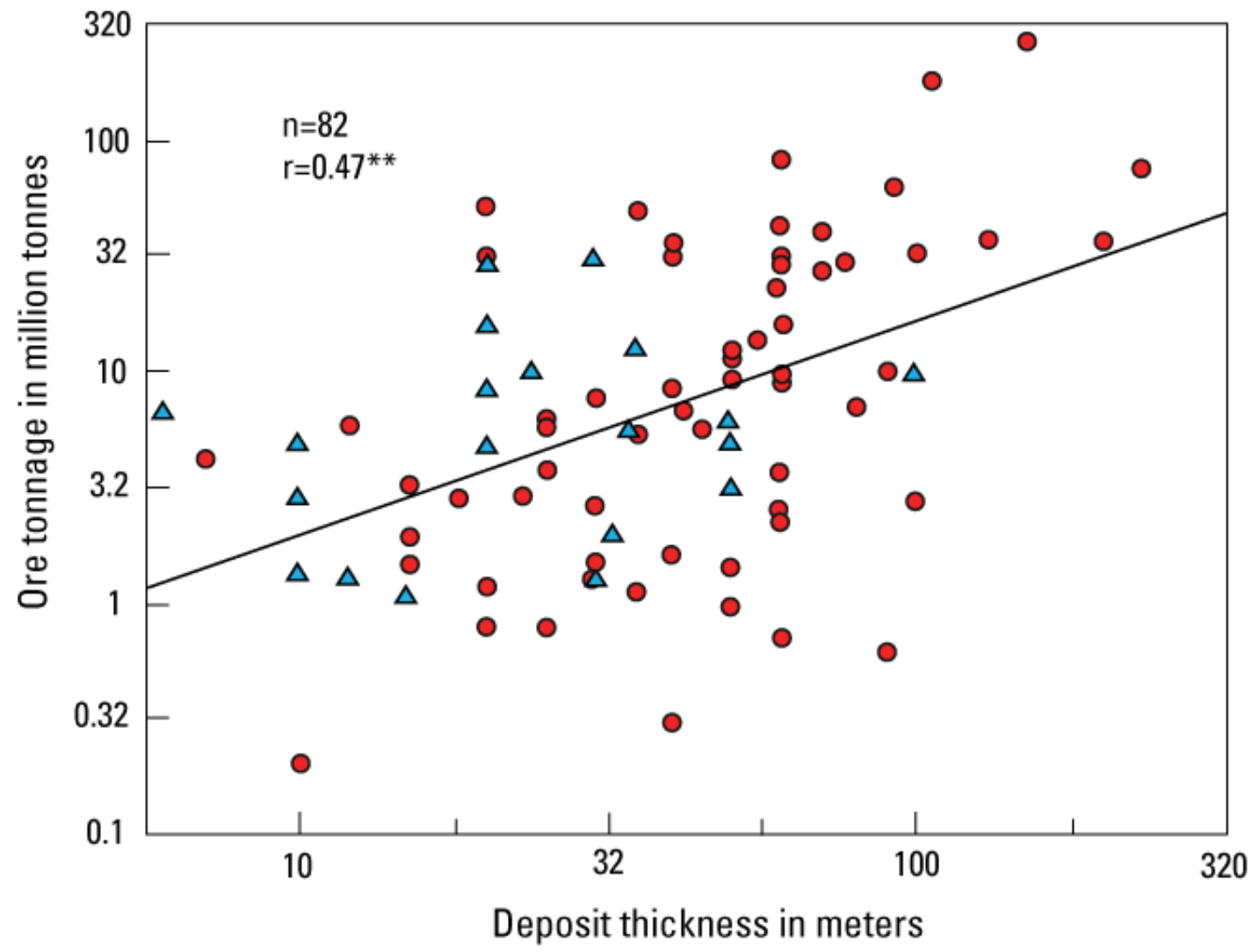

Figure 11. Bivariate plot of tonnages by thickness of all sediment-hosted gold deposits of the United States (red circles) and China (blue triangles). Circles and triangles indicate individual deposits. ** Significant at the 1 percent level. 


\section{Carlin Subtype Grade and Tonnage Model}

Sediment-hosted gold deposits in the western United States, Malaysia, Indonesia, and Iran (90 deposits) are combined into a subtype called the Carlin-subtype model. Grades, tonnages, mineralogy, and tectonic settings distinguish the Carlin deposits from the Chinese deposits, and they allow for the development of these subtypes.

The Carlin-subtype grade and tonnage model contains 88 deposits with reliable data. The Carlinsubtype tonnage frequency plot is shown in figure 12. The median tonnage is 7.1 Mt. The gold grade frequency plot is displayed in figure 13, where the median grade is $2.0 \mathrm{~g} / \mathrm{t} \mathrm{Au}$. The silver grade frequency plot is shown in figure 14, with $0.78 \mathrm{~g} / \mathrm{t} \mathrm{Ag}$ for the 10th percentile of deposits. Summary statistics are summarized in table 5.

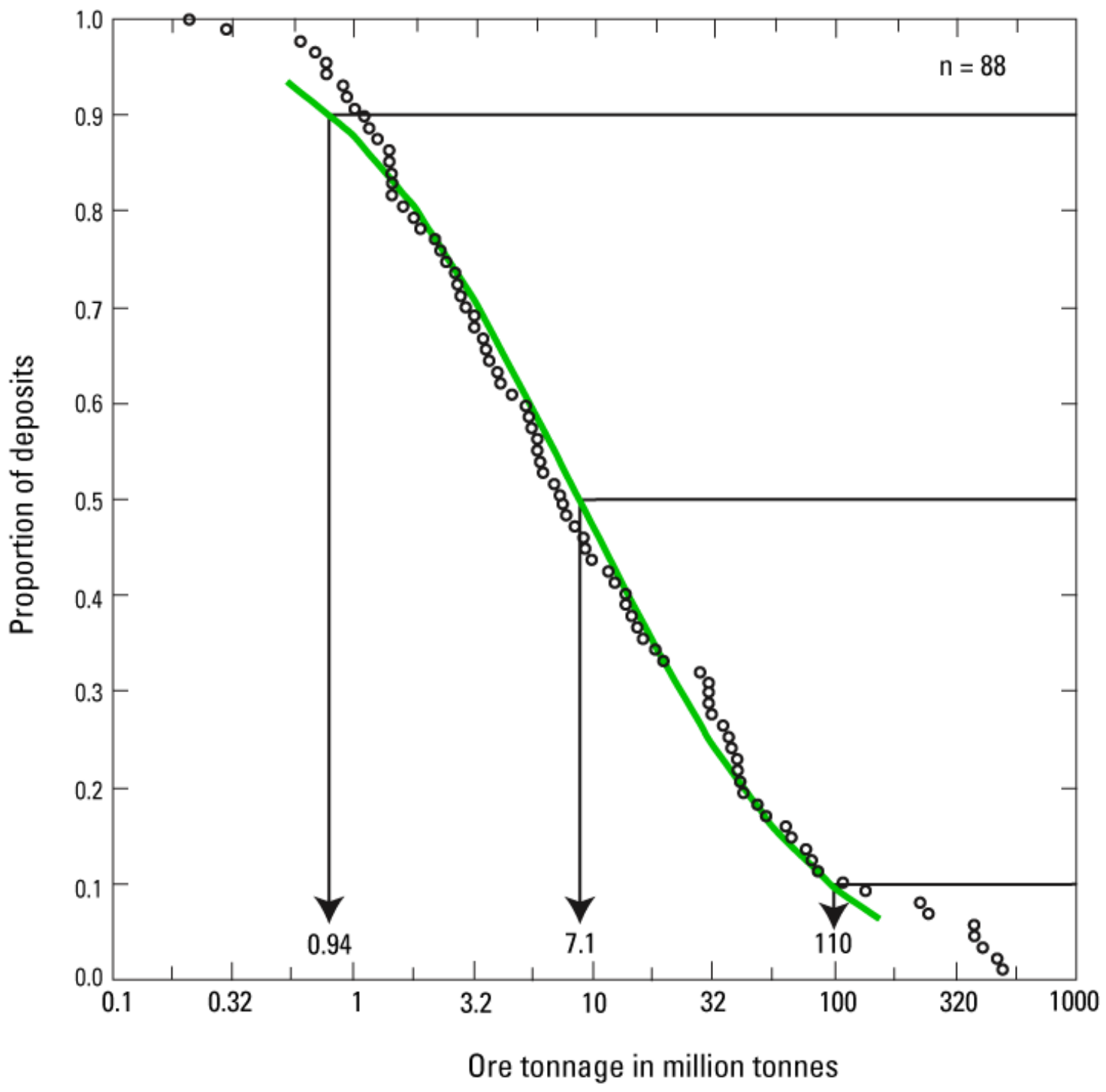

Figure 12. Cumulative frequency plot of ore tonnages for the Carlin subtype of sediment-hosted gold deposit types.

Each circle represents an individual deposit and green line shows tonnage model curve. Intercepts for the 90th, 50th, and 10th percentiles of the observed distribution are provided. 


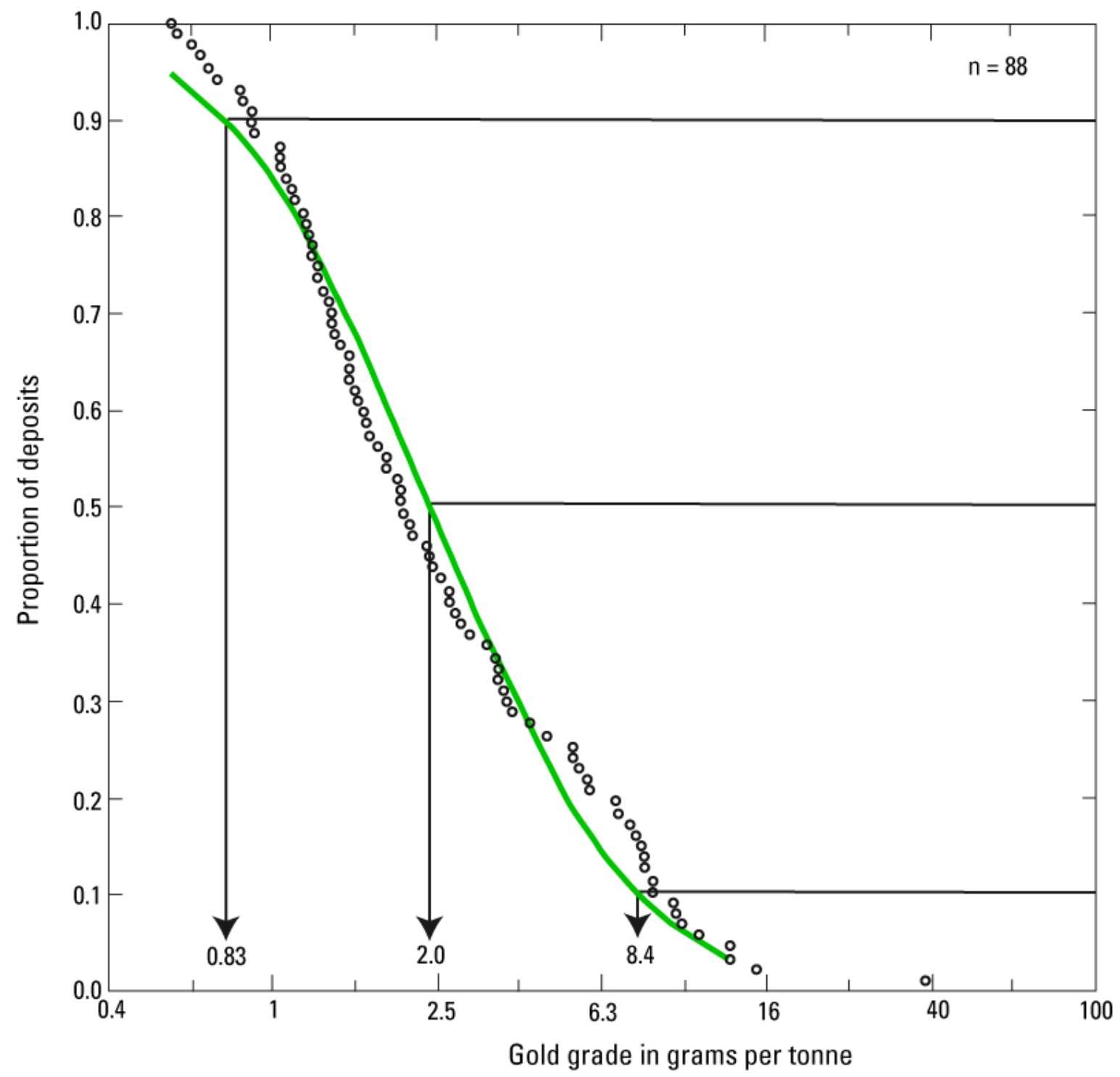

Figure 13. Cumulative frequency plot of gold grades for the Carlin subtype of sediment-hosted gold deposit types. Each circle represents an individual deposit and green line shows gold grade model curve. Intercepts for the 90th, 50th, and 10th percentiles of the observed distribution are provided. 


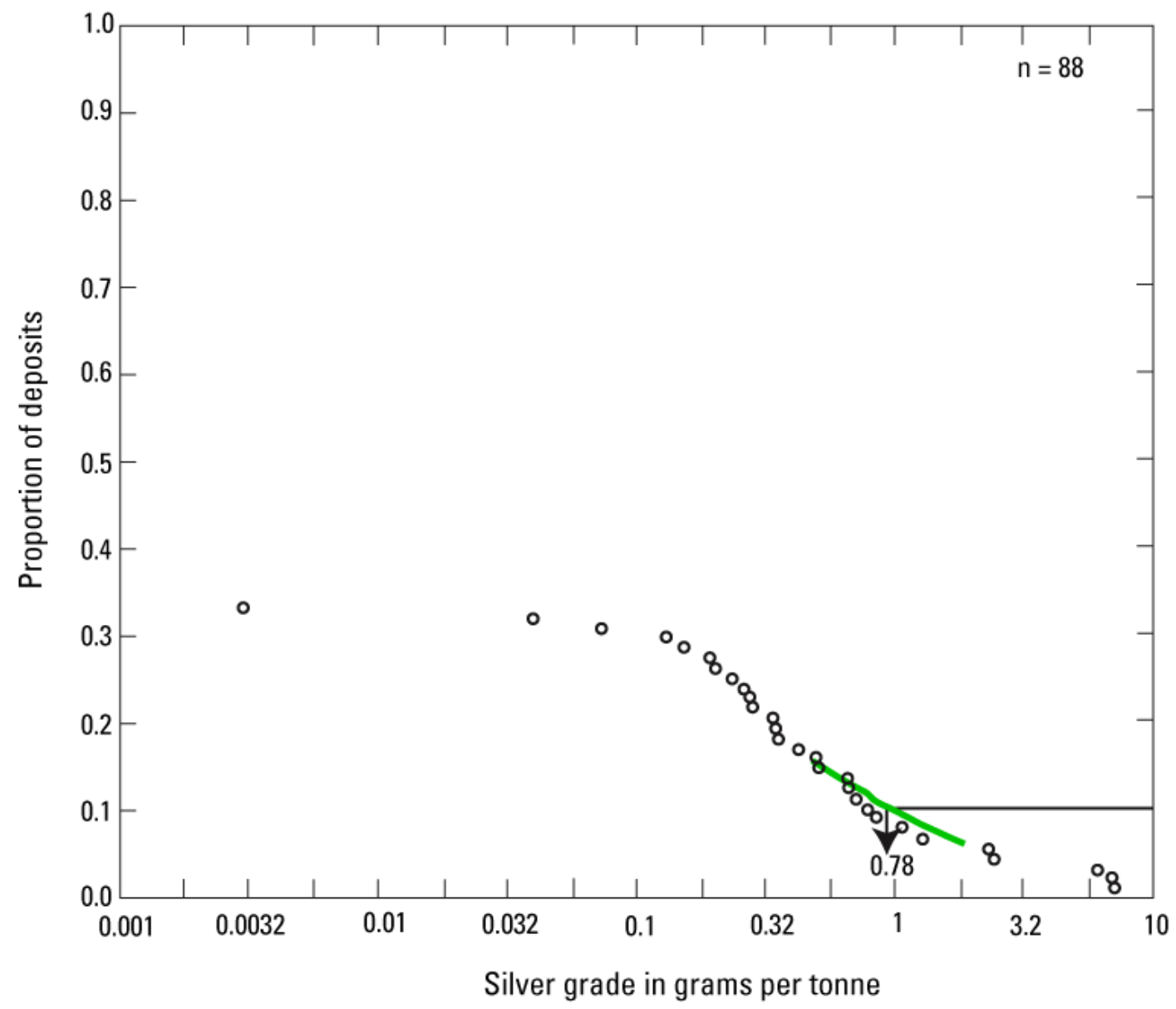

Figure 14. Cumulative frequency plot of silver grades for the Carlin subtype of sediment-hosted gold deposit types. Each circle represents an individual deposit and green line shows silver grade model curve. Intercept for the 10th percentile of the observed distribution is provided.

Previous tonnage and grade models of the Carlin subtype of sediment-hosted gold deposits constructed by Bagby and others (1986) and Mosier and others (1992) are remarkably similar to our model even though twice the number of deposits and modern data compilation are used in the present analysis. The difference between the 90th and 50th percentiles in the earlier models and in the present model is no more than 20 percent. However, the 10th percentiles of tonnages and of gold grades increased substantially indicating giant sediment-hosted gold deposits are remarkably larger then previously reported. One notable change in grade and tonnage models since the publications by Bagby and others (1986) and Mosier and others (1992), is that reporting of silver has expanded from 7 percent to 25 percent of all deposits in the data. The increased number of deposits in the present model allowed addition of the 10th percentile for silver grades due to the available number of reported silver grades. The Chinese subtype was not considered in the earlier models.

Ninety-seven percent of the Carlin-subtype deposits are found in cratonic settings, with the remainder found in sedimentary units of fold belts or magmatic arcs. In two of the cratonic settings, foreland basin and imbricate structure, all deposits are of this subtype. Statistical analyses (table 6) show that deposits in the setting of imbricate structure have the largest median tonnage and contained gold of all tectonic settings.

Minerals and alteration types in the Carlin subtype deposits are listed in table 11. Micron-scale gold is found in decreasing order of occurrence in pyrite, quartz, Fe-oxide, As-pyrite, and clay minerals. Native gold was reported in 60 percent of the deposits and native silver in only 4 percent of the deposits. 
Pyrite is present in 84 percent of the deposits. Other minerals found in minor amounts in decreasing order of occurrence include arsenopyrite, hematite, stibnite, sphalerite, realgar, limonite, goethite, marcasite, orpiment, As-pyrite, cinnabar, galena, tetrahedrite/tennantite, and chalcopyrite.

Alteration types more commonly found in the Carlin-subtype deposits include argillization, decalcification or decarbonatization, silicification to jasperoid, and silicification.

Table 11. Frequency of the main minerals grouped by the Carlin and Chinese subtypes of sediment-hosted gold deposit types.

[Count, number of deposits; \%, percent of deposits containing the mineral.]

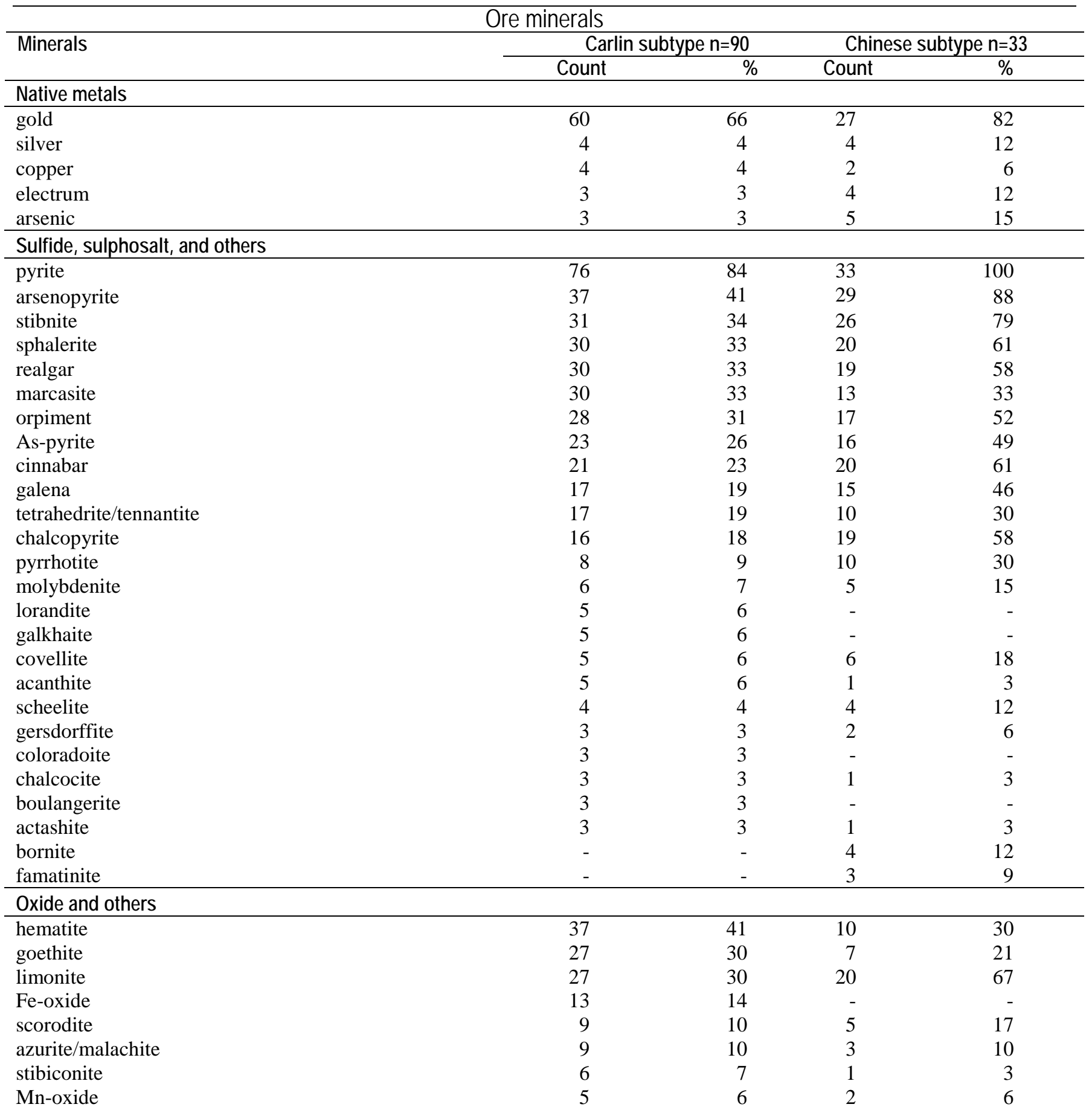




\begin{tabular}{|c|c|c|c|c|}
\hline magnetite & 4 & 4 & 8 & 24 \\
\hline rutile + anatase & 4 & 4 & 8 & 24 \\
\hline valentinite & - & - & 3 & 10 \\
\hline \multicolumn{5}{|c|}{ Gangue minerals } \\
\hline \multirow[t]{2}{*}{ Minerals } & \multicolumn{2}{|c|}{ Carlin subtype $n=90$} & \multicolumn{2}{|c|}{ Chinese subtype $n=33$} \\
\hline & Count & $\%$ & Count & $\%$ \\
\hline quartz & 83 & 92 & 32 & 97 \\
\hline Kaolinite + clay minerals & 74 & 82 & 21 & 64 \\
\hline barite & 53 & 59 & 19 & 58 \\
\hline calcite & 47 & 52 & 25 & 76 \\
\hline illite & 44 & 49 & 11 & 33 \\
\hline dolomite & 41 & 46 & 20 & 61 \\
\hline muscovite/sericite & 21 & 23 & 28 & 85 \\
\hline jarosite & 15 & 17 & 4 & 12 \\
\hline bitumen (pyrobitumen, oil, etc.) & 15 & 17 & 8 & 24 \\
\hline alunite & 13 & 15 & 1 & 3 \\
\hline montmorillonite & 12 & 14 & 4 & 12 \\
\hline siderite & 7 & 8 & 6 & 18 \\
\hline fluorite & 6 & 7 & 9 & 27 \\
\hline dickite & 6 & 7 & 6 & 18 \\
\hline smectite & 5 & 6 & 1 & 3 \\
\hline chalcedony & 5 & 6 & 7 & 21 \\
\hline apatite & 5 & 6 & 6 & 18 \\
\hline gypsum & 4 & 4 & 5 & 15 \\
\hline epidote & 4 & 4 & 4 & 12 \\
\hline chlorite & 4 & 4 & 10 & 30 \\
\hline ankerite & 4 & 4 & 8 & 27 \\
\hline halloysite & 3 & 3 & - & - \\
\hline garnet & 3 & 3 & 1 & 3 \\
\hline diopside & 3 & 3 & - & - \\
\hline feldspar & 2 & 2 & 4 & 13 \\
\hline biotite & 2 & 2 & 3 & 10 \\
\hline graphite & 1 & 1 & 3 & 10 \\
\hline tourmaline & 2 & 2 & 2 & 7 \\
\hline \multicolumn{5}{|c|}{ Main minerals hosting micro-grained gold } \\
\hline \multirow[t]{2}{*}{ Minerals } & \multicolumn{2}{|c|}{ Carlin subtype $n=90$} & \multicolumn{2}{|c|}{ Chinese subtype $n=33$} \\
\hline & Count & $\%$ & Count & $\%$ \\
\hline pyrite & 22 & 35 & 17 & 68 \\
\hline quartz & 22 & 35 & 6 & 24 \\
\hline Fe-oxide & 21 & 34 & 9 & 36 \\
\hline As-pyrite & 15 & 24 & 12 & 48 \\
\hline kaolinite + clay minerals & 9 & 15 & 4 & 16 \\
\hline marcasite & 6 & 10 & - & - \\
\hline arsenopyrite & 1 & 2 & 8 & 32 \\
\hline carbonate & - & - & 4 & 16 \\
\hline sericite & - & - & 3 & 12 \\
\hline \multicolumn{5}{|c|}{ Main host-rock alteration varieties } \\
\hline \multirow{2}{*}{ Alteration mode } & \multicolumn{2}{|c|}{ Carlin subtype $n=90$} & \multicolumn{2}{|c|}{ Chinese subtype $n=33$} \\
\hline & Count & $\%$ & Count & $\%$ \\
\hline argillization & 71 & 79 & 12 & 36 \\
\hline decalcification and decarbonatization & 67 & 74 & 1 & 3 \\
\hline silicification to jasperoid & 47 & 52 & 3 & 9 \\
\hline silicification & 36 & 40 & 30 & 91 \\
\hline contact metamorphism (skarn, hornfels) & 17 & 19 & 3 & 9 \\
\hline carbonization & 15 & 17 & 5 & 15 \\
\hline carbonatization & 11 & 12 & 10 & 30 \\
\hline sulfidization & 7 & 8 & 11 & 33 \\
\hline sericitization & 3 & 3 & 10 & 30 \\
\hline
\end{tabular}




\section{Chinese Subtype Grade and Tonnage Model}

Sediment-hosted gold deposits in China (33 deposits) are grouped into the Chinese subtype. The Chinese-subtype grade and tonnage model contains 30 deposits with reliable data. Statistics are summarized in table 5 . The tonnage frequency plot for the Chinese-subtype is in figure 15 . The median tonnage is 3.9 Mt. The gold grade frequency plot is shown in figure 16, with the median grade of $4.6 \mathrm{~g} / \mathrm{t}$ $\mathrm{Au}$. There are not enough reported silver grades to construct a silver frequency plot.

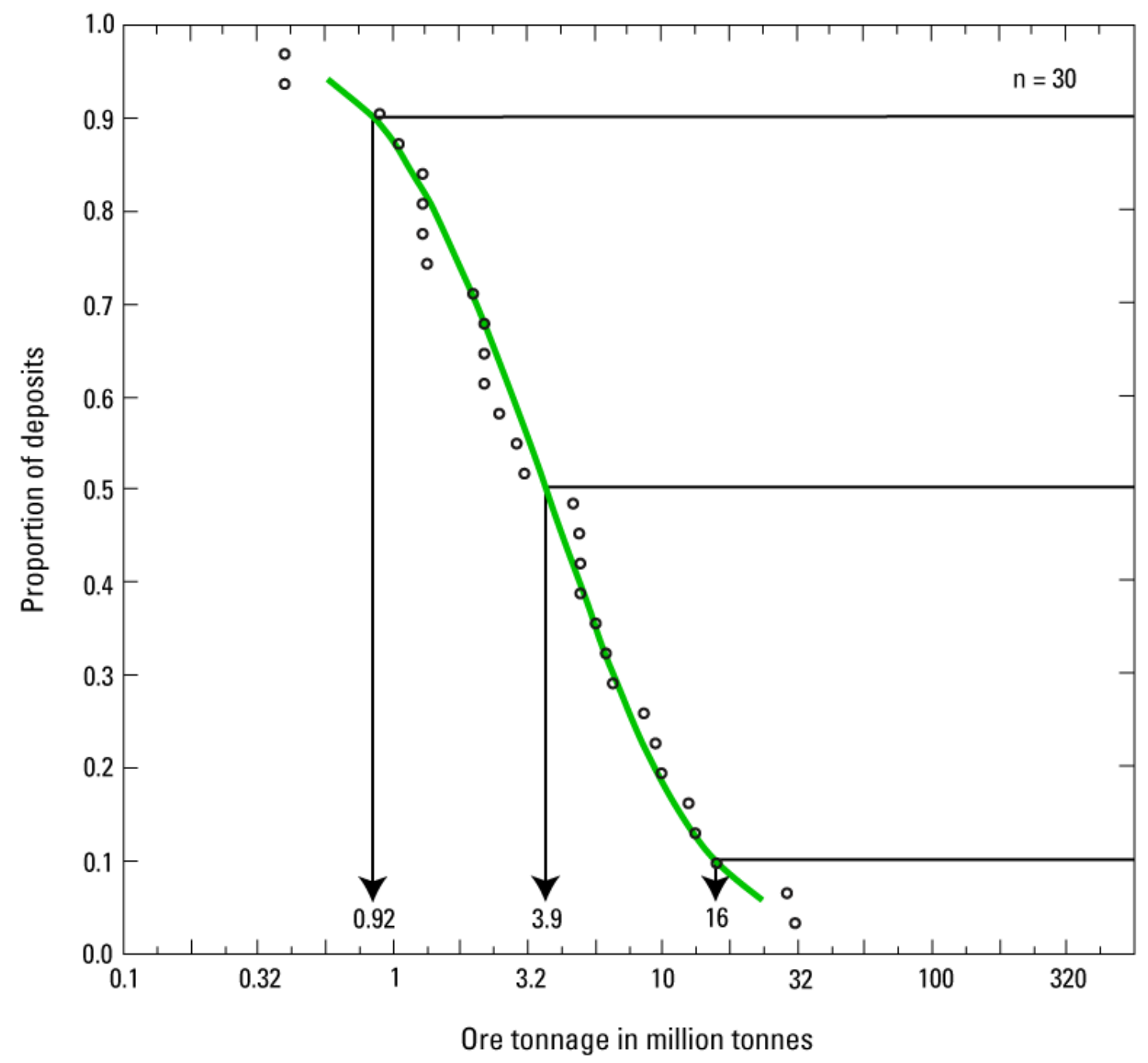

Figure 15. Cumulative frequency plot of ore tonnages for the Chinese subtype of sediment-hosted gold deposit types. Each circle represents an individual deposit and green line shows tonnage model curve. Intercepts for the 90th, 50th, and 10th percentiles of the observed distribution are provided. 


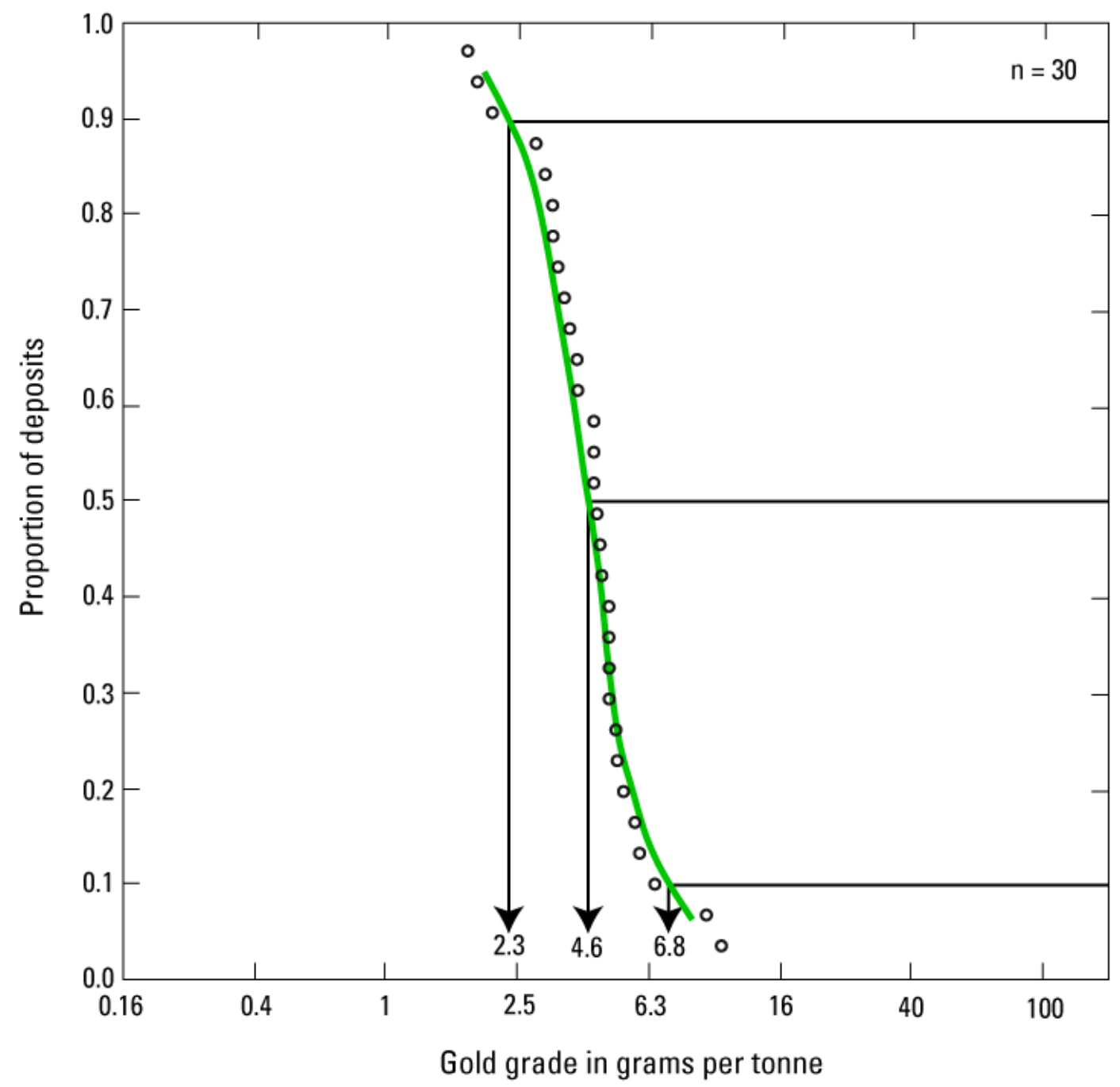

Figure 16. Cumulative frequency plot of gold grades for the Chinese subtype of sediment-hosted gold deposit types. Each circle represents an individual deposit and green line show gold grade model curve. Intercepts for the 90th, 50th, and 10th percentiles of the observed distribution are provided.

Tectonic settings that contain deposits of the Chinese-subtype are cratonic platforms of the South China craton (19 deposits) and fold belts of Cambrian to Cretaceous age. The latter setting contains 14 deposits, mostly in the Qingling fold belt and one in the Yangtze River fold belt.

Minerals and alteration types in the Chinese-subtype deposits are listed in table 11. In decreasing order of importance, micron-sized gold is found in pyrite, As-pyrite, Fe-oxide, arsenopyrite, quartz, clay minerals, carbonate, and sericite. Native gold was reported in 82 percent of the deposits and native silver in 12 percent of the deposits. Pyrite is ubiquitous. Other significant minerals in decreasing order of occurrence include arsenopyrite, stibnite, limonite, sphalerite, cinnabar, chalcopyrite, realgar, orpiment, As-pyrite, galena, marcasite, pyrrhotite, tetrahedrite/tennantite, and hematite.

Alteration commonly found in the Chinese-subtype deposits in decreasing order includes silicification, argillization, sulfidization, carbonatization, and sericitization. 


\section{Grade and Tonnage Differences of Carlin and Chinese Subtypes}

Results of this study suggest that there are differences in deposit size and gold grade between the Carlin and Chinese subtypes. In China, more than 30 sediment-hosted gold deposits of this type have been described (Zaw and others, 2007) and a quantitative comparison of the Chinese subtype was made to those identified as Carlin subtype gold deposits in the United States and in the other countries. Box plots suggest the two groups may differ in tonnage and gold grades (fig. 17, table 12). Tonnages of the Carlin subtype are significantly higher than those of the Chinese subtype at the 1-percent level (fig. 17A). Gold grades of the Chinese subtype are higher than in the Carlin subtype and the difference is significant at the 1-percent confidence level (fig. 17B). Carlin subtype deposits are over two times larger in median tonnage and over two times lower in the median gold grade compared to Chinese deposits; however, contained gold is not significantly different between the subtypes.

Table 12. Tonnage and gold grades of the Carlin and Chinese subtypes of the sediment-hosted gold deposit types. $\left[{ }^{1}\right.$ General, total numeric characteristics of all deposits in the data set. ${ }^{2}$ Tonnage reported in metric tons. ${ }^{3}$ Significant differences between median values of the two groups at the $1 \%$ level or less are indicated in bold.]

\begin{tabular}{|c|c|c|c|c|c|c|c|c|}
\hline \multirow{2}{*}{$\begin{array}{c}\text { Sediment- } \\
\text { hosted Au } \\
\text { model type and } \\
\text { subtypes }\end{array}$} & \multirow{2}{*}{$\begin{array}{l}\text { Number } \\
\text { deposits }\end{array}$} & \multicolumn{3}{|c|}{ Total ore tonnage $^{2}$} & \multirow{2}{*}{$\begin{array}{l}\text { Median Au } \\
\text { grade, g/t }\end{array}$} & \multicolumn{3}{|c|}{ Total contained gold } \\
\hline & & $\begin{array}{l}\text { Ore, } \\
\text { million } \\
\text { tonnes }\end{array}$ & $\%$ & $\begin{array}{l}\text { Median, } \\
\text { million } \\
\text { tonnes }\end{array}$ & & $\begin{array}{c}\mathrm{Au} \\
\text { tonnes }\end{array}$ & $\%$ & $\begin{array}{c}\text { Median, } \\
\text { Au tonnes }\end{array}$ \\
\hline General $^{1}$ & 118 & 4,211 & 100 & 5.7 & 2.9 & 9,631 & 100 & 19 \\
\hline Carlin subtype & 88 & 4,017 & 95 & $7.0^{3}$ & 2.03 & 8,784 & 89 & 21 \\
\hline $\begin{array}{l}\text { Chinese } \\
\text { subtype }\end{array}$ & 30 & 194 & 5 & 3.9 & 4.55 & 847 & 11 & 15 \\
\hline
\end{tabular}



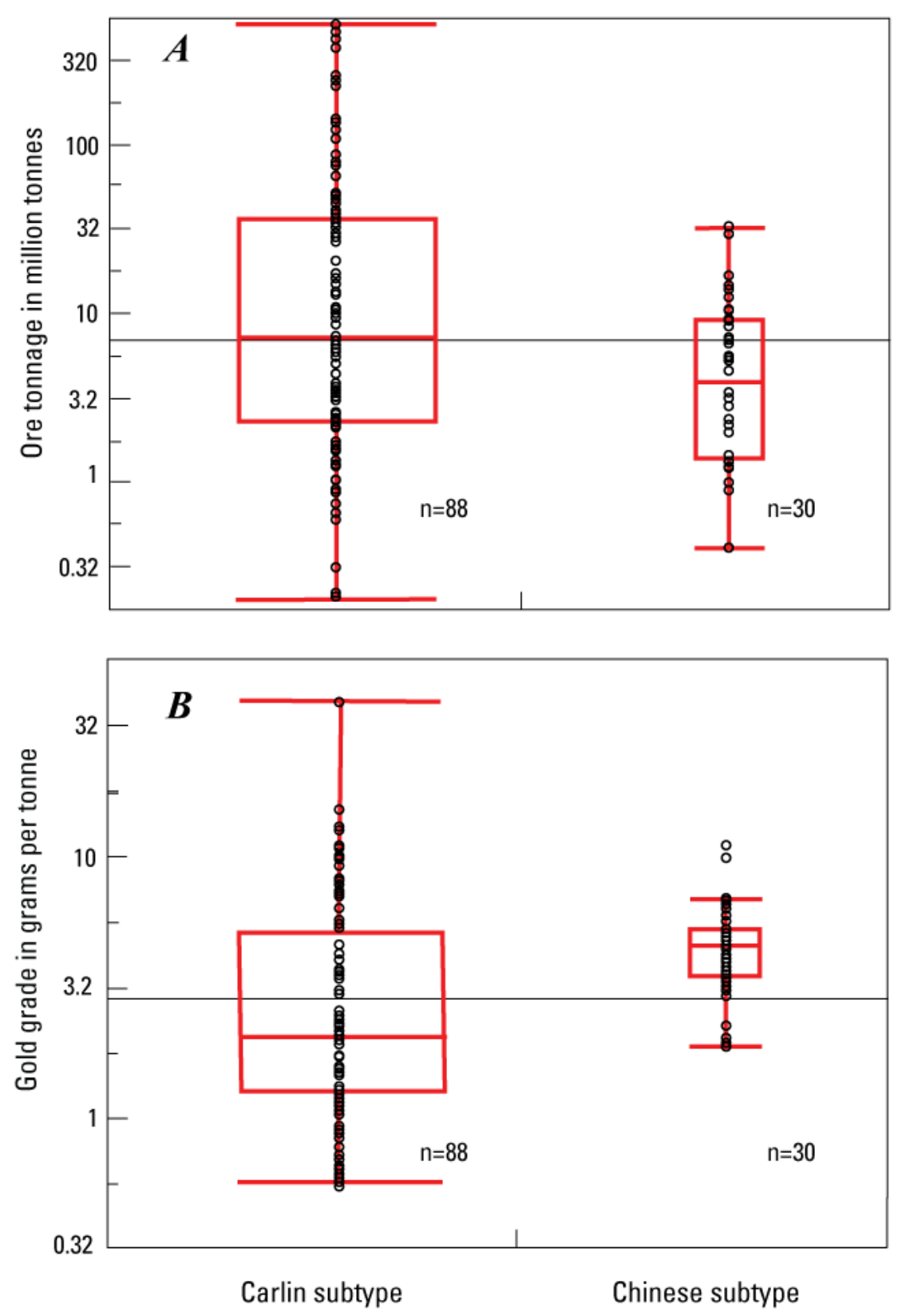

Figure 17. Box plots of sediment-hosted gold deposits of Carlin and Chinese subtypes. $A$, Tonnages, $B$, Gold grades. Circles represent individual deposit tonnages, median value is the center line of box, 25th and 75th quartiles are top and bottom of box, the upper line is the 100 percentile, the lower line is the 0 percentile, and the line across the plot is the grand mean. Box plot width is proportional to sample size.

For the total of all deposits, the correlation (fig. 18) between ore tonnage and contained gold is positive ( $\mathrm{r}=0.88$ and is significant at 1 percent level), with a linear fit regression equation of $y=0.54+0.87 x$, where ' $y$ ' is $\log _{10}$ of contained gold in tonnes and ' $x$ ' is $\log _{10}$ of ore in million tonnes (fig. 18A). There is a positive correlation between contained gold and gold grade, which is significant at the 5-percent level; the linear fit regression equation is $y=1.1+0.4 x$, where ' $y$ ' is $\log _{10}$ of contained gold in tonnes and ' $x$ ' is $\log _{10}$ of gold grade in grams per tonne (fig. 18B). The correlation between ore tonnage and gold grade is negative ( $\mathrm{r}=-0.27$ and is significant at 1 percent level), with a linear fit regression equation of $y=0.57-0.13 x$, where ' $y$ ' is $\log _{10}$ of gold grade in grams per tonne, and ' $x$ ' is $\log _{10}$ of ore in million tonnes (fig. 18C). 

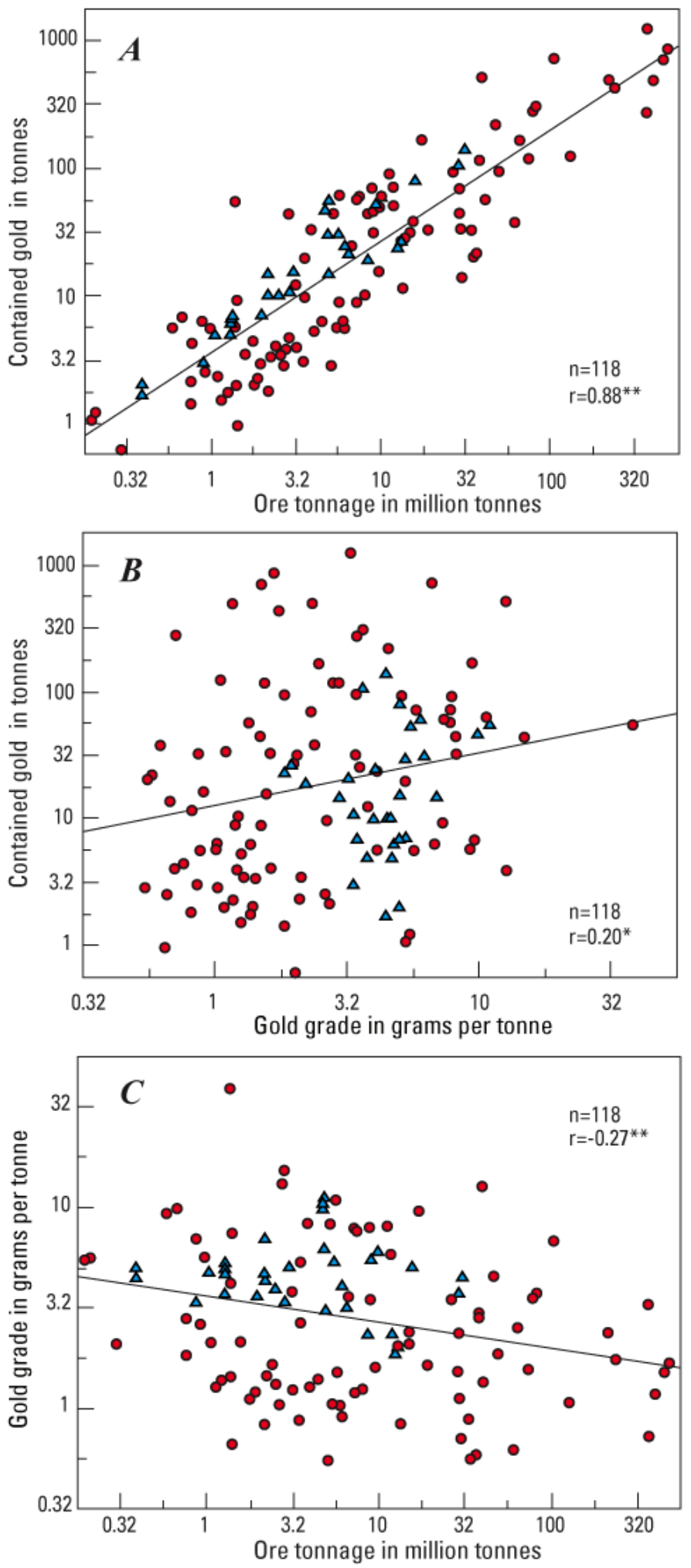

Figure 18. Bivariate plots of the entire sediment-hosted gold deposit population including Carlin (red circles) and Chinese (blue triangles) subtypes: $A$, Contained gold by deposit tonnages, $B$, Contained gold by gold grade, $C$, gold grade by deposit tonnages. See text for correlations and regression equations. In both plots, circles and triangles indicate individual deposits. ${ }^{* \star}$ Significant at the 1 percent level; * significant at the 5 percent level. 
The significant negative correlation between gold grades and tonnages in the total group does not exist in the individual subtypes, indicating that the correlation in the total group was induced by combining different populations (the subtypes). Gold grades in deposits of the Carlin subtype are skewed to higher value, which may explain rejection of the gold grade normal distribution in the subset. Gold grade distributions may be skewed by mine operations transitioning from open pit to underground mining of high-grade refractory ores.

Most silver grade data are from 29 Carlin-type deposits in Nevada and the Bau deposit in Malaysia. The lowest silver grade of $0.003 \mathrm{~g} / \mathrm{t}$ was reported from the Griffon deposit; the highest average grade of $6.8 \mathrm{~g} / \mathrm{t} \mathrm{Ag}$ was from the Northumberland deposit, where silver grades in the open pit resources reached $7.69 \mathrm{~g} / \mathrm{t} \mathrm{Ag} \mathrm{(Fronteer} \mathrm{Gold} \mathrm{Inc.,} \mathrm{2009)} \mathrm{and} \mathrm{from} \mathrm{the} \mathrm{Storm} \mathrm{deposit,} \mathrm{where} \mathrm{silver} \mathrm{grade}$ is near $7 \mathrm{~g} / \mathrm{t} \mathrm{Ag}$ (Nevada Bureau of Mines and Geology, 2011). These high silver contents may be caused by superposed epithermal mineralization (Trotman, 2009). The median silver grade of the Carlin subtype subset is $0.42 \mathrm{~g} / \mathrm{t}$ Ag, but this cannot be representative because less than half of the deposits in this subset have reported silver. Bivariate plots of silver grade by tonnage and silver grade by gold grade illustrate insignificant correlations.

Statistical differences in tonnage and grades between Carlin and Chinese subtypes may be due partly to the mining method used in China, where many small- to medium-size gold deposits were exploited using small-scale mining methods.

\section{Mineralogical Differences In the Carlin and Chinese Subtypes}

The sediment-hosted gold deposit data are divided into two groups corresponding to Carlin subtype in one group and Chinese subtype in another (table 11). Of the 100 minerals recorded, 80 are included in tables in order of decreasing percentage for the United States group followed by data for the China group. This format allows direct comparison of mineral lists between the two groups and reveals notable mineralogical similarities and differences:

1. Mineralogical similarities in the two subtypes are indicated by predominantly invisible micron-sized gold contained mostly as inclusions in pyrite, As-pyrite (arsenic-enriched pyrite is widespread in sediment-hosted gold deposits), quartz, iron-oxide, and clay minerals. Reported sizes of disseminated gold particles not visible to visual examination range from 0.1 to 20 microns. Visible gold of particle size from tens of microns to 3 millimeters is described in a few deposits of both groups. As a rule, such visible gold is confined to late veinlets and crustified vugs related to late stage mineralization or superposed hydrothermal event (Hall and others, 2000; Krahulek, 2010; Mao and others, 2002; Parraga, 2005, 2010; Peters and others, 2002a,b; Sennitt, 2003).

2. Mineralogical dissimilarities in the two subtypes are as follows:

(a) Arsenopyrite, stibnite, chalcopyrite, pyrrhotite, and magnetite are widely reported in deposits of the Chinese subtype (table 11); they are reported much less frequently in deposits of the Carlin subtype. In addition, arsenopyrite is one of the main gold-bearing minerals in China (32 percent of deposits) and plays an almost negligible role in the Carlin subtype group (2 percent of deposits).

(b) In deposits of the Chinese subtype, carbonate minerals were reported frequently containing calcite (76 percent), dolomite (61 percent), ankerite (27 percent), and siderite (18 percent). Muscovite/sericite (85 percent) and chlorite (30 percent) are also widely distributed. Observations on micron-sized gold hosted by carbonate minerals and sericite are also common. Carbonate minerals and sericite are rarely described as gold-bearing in the Carlin subtype deposits.

(c) Decalcification (or decarbonatization) is the major type of host rock alteration reported in 74 percent of the Carlin subtype deposits. This kind of alteration is reported in just 3 percent of 
the Chinese subtype deposits. Similarly, jasperoids are reported in 52 percent of the Carlin subtype deposits and only in 9 percent of the Chinese subtype deposits, which are distinguished by sericitization (30 percent) that is far less commonly reported in the Carlin subtype deposits (3 percent).

It is unlikely that mineralogical differences reported between the two subtypes of sedimenthosted gold deposits are due to mining methods, as previously suggested for the grade and tonnage data-instead, differences likely result from variability in gold mineralization, deposit mineralogy, and alteration.

\section{Summary}

This compilation contains data on 123 sediment-hosted gold deposits in the Great Basin, western United States, and China, and was developed to update the previous grade and tonnage model prepared by Mosier and other (1992). The database has three times the number of deposits as included in the previous model. Three new grade and tonnage models presented here are (1) a general sediment-hosted gold grade and tonnage model, (2) a Carlin-subtype grade and tonnage model, and (3) a Chinese subtype grade and tonnage model. The Chinese subtype was not considered in the earlier models (Bagby and others, 1986; Mosier and others, 1992). For the new Carlin subtype model, with data on over twice the number of deposits used by Mosier and others (1992), the new grade and tonnage model is remarkable in that the estimated parameters of the resulting distributions are comparable to the previous model at the $90^{\text {th }}$ and $50^{\text {th }}$ percentiles where tonnage and gold grades have changed very little, the 10th percentiles of tonnages and of gold grades increased substantially indicating giant sediment-hosted gold deposits are remarkably larger then previously reported (table 5). A notable change is that silver is now reported in a greater number of deposits (now more than 10 percent) but only for mined sediment-hosted gold deposits. This suggests that the greater number of silver grades is due to better reporting rather than absence of silver in deposits not yet worked. The new general grade and tonnage model for 118 sediment-hosted gold deposits has a median tonnage of $5.7 \mathrm{Mt}$ and Au grade of $2.9 \mathrm{~g} / \mathrm{t}$.

Statistically different groups of sediment-hosted gold deposits occur in craton margins (NorthAmerican and South China cratons) and fold belts. The first major group (craton) includes three subsettings: platform, foreland basin, and imbricate structure. This last group (imbricate structure) represents a small subset of deposits distinguished by the largest median tonnage and contained gold, where mineralization penetrated through stacked autochthonous and allochthonous plates. Statistical tests of two groups of deposits occurring in amagmatic and magmatic environments reveal a significant difference among them in tonnages and the related variable contained gold with the much higher median values in the deposits spatially associated with igneous rocks regardless of structural styles of the deposits. Statistical tests support the suggestion that magmatic environments are critical for the intensity of mineralization regardless of structural styles of deposits. Independently of the genetic interpretations, this conclusion is important in the regional assessment of prospective areas for sediment-hosted gold deposits.

From the general grade and tonnage model, two subtypes of sediment-hosted gold deposits that are statistically different based on tonnage and grades have been identified. One is the Carlin subtype with 88 deposits found mainly in western United States and in Indonesia, Iran, and Malaysia. The median tonnage and grade are $7.1 \mathrm{Mt}$ and $2.0 \mathrm{~g} / \mathrm{t} \mathrm{Au}$. The silver grade is $0.78 \mathrm{~g} / \mathrm{t} \mathrm{Ag}$ for the 10th percentile of deposits. The other is the Chinese subtype with 30 deposits in China, having a median tonnage of 3.9 Mt and medium grade of $4.6 \mathrm{~g} / \mathrm{t} \mathrm{Au}$.

Some notable differences in mineralogy and alteration are recognized in the two sediment-hosted gold subtypes. Arsenopyrite, chalcopyrite, pyrrhotite, and magnetite are widely reported in deposits of the Chinese subtype; they are reported much less frequently in deposits of the Carlin subtype. In addition, arsenopyrite is one of the main gold-bearing minerals in the Chinese subtype and plays an 
almost negligible role in the Carlin subtype. Carbonate minerals, sericite, and chlorite were reported frequently in the Chinese deposits, and micron-sized gold is commonly hosted in carbonate minerals and sericite. Decalcification (or decarbonatization) is the major type of host rock alteration reported in 74 percent of Carlin subtype deposits. This kind of alteration is rarely observed or reported in Chinese deposits. Similarly, jasperoids are known in half of deposits of the Carlin subtype and only in 9 percent of the Chinese subtype, which is distinguished by sericitization that is far less commonly reported in the Carlin subtype.

The significant difference of gold grade and ore tonnage between the Carlin and Chinese subtypes and the corresponding mineralogical distinctions raise some doubts about the proposed classification as "Carlin type" or "Carlin-like” of sediment-hosted gold deposits in China (Chen and others, 2011; Hu and others, 2002; Liu and others, 2000; Mao and others, 2002; Peters and others, 2002a,b; Zaw and others, 2007). This uncertainty is emphasized by the recent publication of Goldfarb and others (2014) where sediment-hosted gold deposits of West Qinling, included in the Chinese subtype in this paper, are "better defined as orogenic gold deposits." Ted Theodore (oral communication, 2014), after visiting the sediment-hosted Jinfeng gold deposit in West Qinling, China, also noted that some characteristics of the deposit are more typical of orogenic gold mineralization.

In consideration of the tonnage and grade data and geologic characteristics of sediment-hosted gold deposits, we recommend the use of the three grade and tonnage models presented in the study for mineral resource assessments. The use of a specific model depends on the availability of geologic and mineralogical data for the region being assessed.

\section{Acknowledgments}

We thank Don Singer, Ted Theodore, and Steve Box for their comprehensive reviews, and important comments and helpful advice. We also highly appreciate the additional comments and corrections from Mark Cocker, Robert Miller, and Sarah Nagorsen. Finally, we are grateful to Thomas Frost for his critical notes and recommendations.

\section{References}

Arehart, G.B., Chakurian, A.M., Tretbar, D.R., Christensen, J.N., McInnes, B.A., and Donelick, R.A., 2003, Evaluation of radioisotope dating of Carlin-type deposits in the Great Basin, western North America, and implications for deposit genesis: Economic Geology, v. 98, p. 235-248.

Armstrong, A.K., Theodore, T.G., Kotlyar, B.B., Lauha, E.G., Griffin, G.L., Lorge, D.L., and Abbott, E.W., 1997, Preliminary facies analysis of Devonian autochthonous rocks that host gold along the Carlin trend, Nevada, in Vikre, P., Thompson, T.B., Bettles, K., Christensen, O., and Parratt, R., eds., Carlin-type gold deposits: Field Conference of Society of Economic Geologists, Guidebook Series, v. 28, p. 53-73.

Asadi, H.H., Voncken, J.H.L., Kühnel, R.A., and Hale, M., 2000, Petrography, mineralogy, and geochemistry of the Zarshuran Carlin-type gold deposit, Iran: Mineralium Deposita, v. 35, p. 656-671.

Bagby, W.C., Menzie, W.D., Mosier, D.L., and Singer, D.A., 1986, Grade and tonnage model of carbonate-hosted Au-Ag, in Cox, D.P., and Singer, D.A., eds., Mineral deposit models: U.S. Geological Survey Bulletin 1693, p. 175-177.

Bedell, R., Struhsacker, E., Craig, L., Miller, M., Coolbaugh, M., Smith, J., and Parrat, R., 2010, The Pequop mining district, Elko county, Nevada-An evolving new gold district, in Goldfarb, R.J., Marsh, E.E., and Monecke, T., eds., The challenge of finding new mineral resources-Metallogeny, innovative exploration, and new discoveries: Society of Economic Geologists Special Publication 15, p. 29-56. 
Berger B.R., 1986, Descriptive model of carbonate-hosted Au-Ag, in Cox, D.P., and Singer, D.A., eds., Mineral deposit models: U.S. Geological Survey Bulletin 1693, p. 175.

Berger B.R., Bagby, W.C., 1991, The geology and origin of Carlin-type gold deposits, in Foster, R.P., ed., Gold metallogeny and exploration: Glasgow, Blackie and Son, p. 210-248.

Berger, V.I., Theodore, T.G., 2005, Implications of stratabound Carlin-type gold deposits in Paleozoic rocks of north-central Nevada, in Rhoden, H.N., Steininger, R.C., and Vikre, P.G., eds., Geological Society of Nevada Symposium 2005: Window to the World, Reno, Nevada, May 2005, p. 43-78.

Bettles, K., 2002, Exploration and geology, 1962 to 2002, at the Goldstrike property, Carlin trend, Nevada, in Goldfarb, R.J. and Nielsen, R.L., eds., Integrated methods for discovery-Global exploration in the twenty-first century: Society of Economic Geologists Special Publication no. 9, p. 275-298.

Bliss, J.D., ed., 1992, Developments in deposit modeling: U.S. Geological Survey Bulletin 2004, 168 p.

Canadian Securities Administrators, 2001, National instrument 43-101 standards of disclosure for mineral projects: Summary Brochure Canadian Securities Administrators, National Instrument 43-101 Standards of Disclosure for Mineral Projects, Policy Document.

Chakurian, A.M., Arehardt, G.B., Donelick, R.A., Zhang, X., and Reiners, P.W., 2003, Timing constraints of gold mineralization along the Carlin Trend utilizing apatite fission-track, ${ }^{40} \mathrm{Ar} /{ }^{39} \mathrm{Ar}$, and apatite (U-Th)/He methods: Economic Geology, v. 98, p. 1159-1171.

Chen, M., Mao, J., Bierlein, F.P., Norman, T., and Uttley, P.J., 2011, Structural features and metallogenesis of the Carlin-type Jinfeng (Lannigou) gold deposit, Guizhou Province, China: Ore Geology Reviews, v. 43, p. 217-234.

Christensen, O.D., 1993, Carlin trend geologic overview, in Christensen, O.D., ed., Gold deposits of the Carlin trend, Nevada: Society of Economic Geologists Guidebook Series, v. 18, p. 3-26.

Christensen, O., Garwin, S.L., and Mitchell, P.A., 1996, Carlin-type sedimentary rock-hosted disseminated gold deposits around the Pacific: Spokane, Northwest Mining Association, Short Course "New mineral deposit models of the Cordillera," unpaged.

Cline, J.S., 2001, Timing of gold and arsenic sulfide mineral deposition at the Getchell Carlin-type gold deposit, north-central Nevada: Economic Geology, v. 96, p. 75-89.

Cline, J.S., Hofstra, A.H., Muntean, J.L., Tosdal, R.M., and Hickey, K.A., 2005, Carlin-type gold deposits in Nevada - Critical geologic characteristics and viable models, in Hedenquist, J.W., Thompson, J.H.F., Goldfarb, R.J., and Richards, J.P., eds., Economic Geology 100th Anniversary Volume: Society of Economic Geologists, Littleton, Colorado, p. 451-484.

Clode, C.H., Grusing, S.R., Johnston, I.M., and Heitt, D.G., 2002, Geology of the Deep Star gold deposit, in Thompson, T.B., Teal, L., and Meeuwig, R.O., eds., Gold deposits of the Carlin Trend: Nevada Bureau of Mines and Geology Bulletin 111, p. 77-90.

Cox, D.P., and Singer, D.A., eds., 1986, Mineral deposit models: U.S. Geological Survey Bulletin 1693, $379 \mathrm{p}$.

Crafford, E.J., 2000, Overview of regional geology and tectonic setting of the Osgood Mountains region, Humboldt County, Nevada, in Crafford, A.E.J., ed., Geology and ore deposits-The Great Basin and beyond: Geological Society of Nevada Symposium 2000, Field Trip 9, p. 69-83.

Driesner, D., Coyner, A., 2011, Major mines of Nevada, 2010: Nevada Bureau of Mines and Geology, Special Publication P-22, 28 p.

Emsbo, P., Groves, D.I., Hofstra, A.H., and Bierlein, F.P., 2006, The giant Carlin gold province-A protracted interplay of orogenic, basinal, and hydrothermal processes above a lithospheric boundary: Mineralium Deposita, v. 41, p. 517-525.

Emsbo, P., Hutchinson, R.W., Hofstra, A.H., Volk, J.A., Bettles, K.H., Baschuk, G.J., and Johnson, C.A., 1997, Newly discovered Devonian sedex-type base and precious metal mineralization, northern Carlin trend, Nevada, in Vikre, P.,Thompson, T.B., Bettles, K., Christensen, O., and Parratt, R., eds., Carlin- 
type gold deposits field conference: Society of Economic Geologists Guidebook Series, v. 28, p. 109_ 118.

Fronteer Gold Inc., 2009, Northumberland property: Annual Report 2009, p. 21-29, accessed July 21, 2011, at http://quote.morningstar.com/stock-filing/Annual Report/2009/12/31/t.aspx?t= $X A S E: F R G \& f t=40-F \& d=5$.

Fu, S., Gu, X., and Wang, P., 2004, Rb-Sr isotopic compositions of fluid inclusions in the Manaoke gold deposit, northwest Sichuan Province-Constraint for the ore genesis: Geochimica, v. 33, no. 1, p. 9498 (in Chinese with English abstract).

Garwin, S.L., Hendri, D., and Lauricella, P.F., 1995, The geology of the Mesel sediment-hosted gold deposit, North Sulavesi, Indonesia: PACRIM Congress 1995 Proceedings, Australian Institute of Mining and Metallurgy, p. 221-226.

Goldfarb, R.J., Taylor, R.D., Collins, G.S., Goryachev, N.A., and Orlandini, O.F., 2014, Phanerozoic continental growth and gold metallogeny of Asia: Gondwana Research, v. 25, p. 48-102.

Groff, J.A., Heizler, M.T., McIntosh, W.C., and Norman, D.I., 1997, 40Ar/39Ar dating and mineral paragenesis for Carlin-type gold deposits along the Getchell Trend, Nevada-Evidence for Cretaceous and Tertiary gold mineralization: Economic Geology, v. 92, p. 601-622.

Gu, X.X., Liu, J.M., Schulz, O., Vavtar, F., and Zheng, M.H., 2002, Syngenetic origin for the sedimenthosted disseminated gold deposits in NW Sichuan, China-Ore fabric evidence: Ore Geology Reviews, v. 22, p. 91-116.

Hall, C.M., Kesler, S.E., Simon, G., and Fortuna J., 2000, Overlapping Cretaceous and Eocene alteration, Twin Creeks Carlin-type deposit, Nevada: Economic Geology, v. 95, p. 1739-1752.

Han, C., Yuan, W., Yu, F., Tang, Y., and Bao, Z., 2004, Geochemistry of the Dashui gold deposit in west Qinling Mountains, Gansu Province: Acta Geoscientifica Sinica, v. 25, no. 2, p. 127-132 (in Chinese with English abstract).

Hofstra, A.H., Christensen, O.D., 2002, Comparison of Carlin-type Au deposits in the United States, China, and Indonesia-Implications for genetic models and exploration: U.S. Geological Survey Open-File Report 2002-0131, ch. 2, 94 p., accessed August 15, 2011, at pubs.usgs.gov/of/2002/of02131/chapters/OF02-131_chapter2.pdf.

Hofstra, A.H., Cline, J.S., 2000, Characteristics and models for Carlin-type gold deposits, in Hagemann, S.G., and Brown, P.E., eds., Gold in 2000: Reviews in Economic Geology, v. 13, p. 163-220.

Hofstra, A.H., Snee, L.W., Rye, R.O., Folger, H.W., Phinisey, J.D., Loranger, R.J., Dahl, A.R., Naeser, C.W., Stein, H.J., and Lewchuk, M., 1999, Age constraints on Jerritt Canyon and other gold deposits in the western United States-Relationship to Mid-Tertiary extension and magmatism: Economic Geology, v. 94, no. 6, p. 769-802.

Hu, R.-Z., Su, W.-C., Bi, X.-W., Tu, G.-Z., and Hofstra, A., 2002, Geology and geochemistry of Carlintype gold deposits in China: Mineralium Deposita, v. 37, p. 378-392.

Krahulek, K., 2010, Sedimentary rock-hosted gold and silver deposits of the northeastern Basin and Range, Utah, in Steiniger, R., and Pennel, B., eds., Great Basin evolution and metallogeny: DEStech Publications, Inc., Geological Society of Nevada, Symposium 2010 Proceedings, p. 31-62.

Jackson, M., Lane, M., and Leach, B., 2002, Geology of the West Leeville deposit, in Thompson, T.B., Teal, L., and Meeuwig, R.O., eds., Deep deposits along the Carlin Trend: Nevada Bureau of Mines and Geology Bulletin 111, p. 106-114.

Ji, H., Li, C., and Wen, J., 1998, Source of ore-forming material and metallogenic age of the Zheboshan gold deposit, western Sichuan Province, China: Chinese Science Bulletin, v. 43, no. 8, p. 684-690.

JMP, 2002, Statistics and graphics guide: Cary, NC, USA, SAS Institute Inc., 707 p.

Jory, J., 2002, Stratigraphy and host rock controls of gold deposits on the northern Carlin trend, in Thompson, T.B., Teal, L., and Meeuwig, R.O., eds., Gold deposits of the Carlin trend: Nevada Bureau of Mines and Geology Bulletin 111, p. 20-45. 
Leonardson, R.W., Rahn, J.E., 1996, Geology of the Betze-Post gold deposits, Eureka County, Nevada, in Coyner, A.R., and Fahey, P.L., eds., Geology and ore deposits of the American Cordillera: Reno, Nevada, Geological Society of Nevada Symposium 1995 Proceedings, p. 61-94.

Leonardson, R.W., 2010, Barrick Gold Acres structure, in Steiniger, R., and Pennel, B., eds., Great Basin evolution and metallogeny: DEStech Publications, Inc., Geological Society of Nevada, Symposium 2010 Proceedings, p. 17-29.

Liu, J., Zheng, M., Liu, J., and Su, W., 2000, Geochemistry of the Laerma and Qiongmo deposits in the western Qinling Mountains, China: Ore Geology Reviews, v. 17, p. 91-111.

Lu, Y., Li, H., Chen, Y., and Zhang, G., 2006, ${ }^{40} \mathrm{Ar} /{ }^{39} \mathrm{Ar}$ dating of alteration minerals from Zhaishang gold deposit in Minxian County, Gansu Province, and its geological significance: Mineral Deposits, v. 25, no. 5, p. 590-597 (in Chinese with English abstract).

Maher, B.J., 1997, Mississippian sedimentary rock-hosted gold deposits of the eastern Great BasinRelative importance of stratigraphic and structural ore controls, in Vikre, P., Thompson, T.B., Bettles, K., Christensen, O., and Paratt, R., eds., Carlin-type gold deposits, field conference: Society of Economic Geologists Guidebook Series, v. 28, p. 171-182.

Maher, B.J., Browne, Q.J., and McKee, E.H., 1993, Constraints on the age of gold mineralization and metallogenesis in the Battle Mountain-Eureka mineral belt, Nevada: Economic Geology, v. 88, p. 469-478.

Mao, J., Goldfarb, R.J., Zhang, Z., Garwin, S., and Ren, F., 2002, Geology, distribution, and classification of gold deposits in the western Qinling belt, central China: Mineralium Deposita, v. 37, p. 352-377.

Mohling, J.W., 2002, Geology and gold mineralization of the Turf deposit, in Thompson, T.B., Teal, L., and Meeuwig, R.O., eds., Gold deposits of the Carlin Trend: Nevada Bureau of Mines and Geology Bulletin 111, p. 91-105.

Moore, S., 2001, Ages of fault movement and stepwise development of structural fabrics of the Carlin Trend, in Shaddrick, D.R., Zbinden, E., Mathewson, D.C., and Prenn, C., eds., Regional tectonics and structural control of ore-The major gold trends of northern Nevada: Reno, Geological Society of Nevada Special Publication no. 33, p. 71-89.

Mosier, D.L., Singer, D.A., Bagby, W.C., and Menzie, W.D., 1992, Grade and tonnage model of sediment-hosted Au, in Bliss, J.D., ed., Developments in deposit modeling: U.S. Geological Survey Bulletin 2004, p. 26-28.

Muntean, J., 2006, The rush to uncover gold's origins: Geotimes, April 2006, 5 p., accessed February 12, 2011, at http://www.geotimes.org/apr06/feature_GoldOrigins.html.

Muntean, J.L., Cline, J.S., Simon, A.C., and Longo, A.A., 2011, Magmatic-hydrothermal origin of Nevada's Carlin-type gold deposits: Nature Geoscience, v. 4, p. 122-127.

Muntean, J.L., Coward, M.P., and Tarnocai, C.A., 2007, Reactivated Palaeozoic normal faultsControls on the formation of Carlin-type gold deposits in north-central Nevada, in Ries, A.C., Butler, R.W.H., and Graham, R.H., eds., Deformation of the continental crust-The legacy of Mike Coward: London, Geological Society Special Publications 272, p. 571-587.

Myers, L.A., 1993, Geology and mineralization at the Carlin mine, Eureka County, Nevada, in Christensen, O.D., ed., Gold deposits of the Carlin Trend, Nevada: Society of Economic Geologists Guidebook Series, v. 18, p. 27-35.

Nemitz, M.B., McClelland, W.C., 2005, The effects of thrust faulting and associated structural preparation on the distribution of gold in Carlin-type deposits of northeastern Nevada, in Rhoden, H.N., Steininger, R.C., and Vikre, P.G., eds., Symposium 2005-Window to the world: Reno, Nevada Geological Society, p. 283-294.

Nevada Bureau of Mines and Geology, 2011, The Nevada mineral industry, 2010: Nevada Bureau of Mines and Geology Special Publication MI-2010, 151 p. 
Norby, J.W., and Orobona, M.J.T., 2002, Geology and mineral systems of the Mike deposit, in Thompson, T.B., Teal, L., and Meeuwig, R.O., eds., Gold deposits of the Carlin Trend: Nevada Bureau of Mines and Geology Bulletin 111, p. 143-167.

Parraga, R.J., 2005, Geology of the Chukar Footwall mine, Maggie Creek district, Carlin Trend, Nevada-A progress report, in Rhoden, H.N., Steininger, R.C., and Vikre, P.G., eds., Symposium 2005—Window to the world: Reno, Nevada Geological Society, p. 543-562.

Parraga, R.J.A., 2010, Geology of the Chukar Footwall mine, Maggie Creek district, Carlin Trend, Nevada (Abstract): DMUT, Resource sharing, 2 p., accessed April 5, 2011, at http://www.dmut.net/enshowpaper.aspx?id=109682.

Peng, X., Qing, C., Zhang, J., Chao, C., Young, H., and Xu, B., 2010, The research on the geologic characteristics and mineralization control factors of Dashui gold deposit in Maqu, Gansu Province, China: Geoscience and Remote Sensing (IITA-GRS), Second IITA International Conference, p. 235238.

Peters, S.G., Huang, J., Li, Z., Jing, C., and Cai, Q., 2002a, Geology and geochemistry of sedimentary rock-hosted Au deposits of the Dian-Qian-Gui area, Guizhou and Yunnan provinces, and Guangxi district, P.R. China: U.S. Geological Survey Open-File Report 02-131, ch. 3, p. 95-166.

Peters, S.G., Huang, J., and Jing, C., 2002b, Geology and geochemistry of sedimentary rock-hosted Au deposits of the Qinling fold belt (Chuan-Shan-Gan) area, Shaanxi, Sichuan, and Gansu provinces, P.R. China: U.S. Geological Survey Open-File Report 02-131, ch. 4, p. 167-254.

Peters, S.G., Huang, J., Yongji, W., Mihalsky, M.J., and Chenggui, J., 2002c, Geology and geochemistry of sedimentary rock-hosted Au deposits in the Middle-Lower Yangtze River area, Hubei and Anhui provinces, P.R. China: U.S. Geological Survey Open-File Report 02-131, ch. 5, p. 255-337.

Peters, S.G., Huang, J., Li, Z., and Jing, C., 2007, Sedimentary rock-hosted Au deposits of the DianQian-Gui area, Guizhou and Yunnan provinces, and Guangxi district, China: Ore Geology Reviews, v. 31, p. 170-204.

Phinisey, J.D., Hofstra, A.H., Snee, L.W., Roberts, T.T., Dahl, A.R., and Loranger, R.J., 1996, Evidence for multiple episodes of igneous and hydrothermal activity and constraints on the timing of gold mineralization, Jerritt Canyon district, Elko County, Nevada, in Coyner, A.R., and Fahey, P.L., eds., Geology and ore deposits of the American Cordillera: Reno, Geological Society of Nevada Symposium Proceedings, Reno/Sparks, p. 15-39.

Poole F.G., Sandberg, C.A., and Boucot, A.J., 1977, Silurian and Devonian paleogeography of the western United States, in Stewart, J.H., Stevens, C.H., and Fritsche A.E, eds., Paleozoic paleogeography of the western United States: Los Angeles, Pacific Section of Society of Economic Paleontologists and Mineralogists, p. 39-65.

Presnell, R.D., Parry, W.T., 1996, Geology and geochemistry of the Barneys Canyon gold deposit, Utah: Economic Geology, v. 91, p. 273-288.

Ressel, M.W., Noble, D.C., Heizler, M.T., Volk, J.A., Lamb, J.B., Park, D.E., Conrad, J.E., and Mortensen, J.K., 2000, Gold-mineralized Eocene dikes at Griffin and Meikle-Bearing on the age and origin of deposits of the Carlin Trend, Nevada, in Cluer, J.K., Price, J.G., Struhsacker, E.M., Hardyman, R.F., and Morris, C.L., eds., Geology and ore deposits 2000-The Great Basin and beyond: Reno, Geological Society of Nevada, v. 1, p. 79-101.

Ressel, M.W., Henry, C.D., 2006, Igneous geology of the Carlin Trend, Nevada-Development of the Eocene plutonic complex and significance for Carlin-type gold deposits: Economic Geology, v. 101, p. 347-383.

Roberts, R.J., 1966, Metallogenic provinces and mineral belts in Nevada: Nevada Bureau of Mines Report 13, pt. A, p. 47-72.

Sennitt, C.M., 2003, Technical report of the Laerma, Dashui, and Xiahe properties, Gannan Prefecture, Gansu Province, People Republic of China: Technical Report for Pargas Enterprises Ltd., 184 p., accessed September 29, 2011, at http://www.infomine.com/index/pr/Pa159648.PDF. 
Sha, P., 1993, Geochemistry and genesis of sediment-hosted disseminated gold mineralization at the Gold Quarry mine, Nevada: Tuscaloosa, Alabama, University of Alabama, Ph.D. Dissertation, 228 p. Sillitoe, R.H., Bonham, H.F., Jr., 1990, Sediment-hosted gold deposits-Distal products of magmatichydrothermal systems: Geology, v. 18, p. 157-161.

Singer, D.A., Menzie, W.D., 2010, Quantitative mineral resource assessment-An integrated approach: New York, Oxford University Press, 219 p.

Singer, D.A., Berger, V.I., and Moring, B.C., 2009, Sediment-hosted zinc-lead deposits of the worldDatabase and grade and tonnage models: U.S. Geological Survey Open-File Report 09-1252, accessed February 12, 2011, at http://pubs.usgs.gov/of/2009/1252/.

Streiff, R., 2000, Deep Post mine geology, in Griffin, L., ed., Geology and ore deposits—The Great Basin and beyond: Geological Society of Nevada Symposium 2000, Field Trip 7, p. 101-106.

Su, W., Hu, R., Xia, B., Xia, Y., and Liu, Y., 2009, Calcite Sm-Nd isochron age of the Shuiyindong Carlin-type gold deposit, Guizhou, China: Chemical Geology, v. 258, p. 269-274.

Teal, L., Jackson, M., 1997, Geologic overview of the Carlin trend gold deposits and descriptions of recent deep discoveries: SEG Newsletter, no. 31, p. 1, 13-25.

Theodore, T.G., Moring, B.C., Chadwick, T., Dobak, P.J., Cluer, J.K., and Fleck, R.J., 2006, Geologic map of the Santa Renia Fields Quadrangle, Elko and Eureka counties, Nevada: Nevada Bureau of Mines and Geology, Map 155, 1:24,000 scale.

Trexler, J.H., Jr., Snyder, W.S., Cashman, P.H., Gallegos, D.M., and Spinosa, C., 1991, Mississippian trough Permian orogenesis in eastern Nevada, in Cooper, J.D., and Stevens, C.H., eds., Paleozoic paleography of the western United States-II, v. 1: Los Angeles, Pacific Section of Society of Economic Paleontologists and Mineralogists, p. 317-329.

Trotman, R.B., 2009, Geology of the Storm gold-silver deposit Elko County, Nevada: Reno, University of Nevada, M.S. Thesis, 93 p.

U.S. Geological Survey, 2011, Mineral commodity summaries-Gold: p. 26-27.

Wang, K.-R., and Zhou, Y.-Q., 1994, Mineralogy of the Carlin-type Dongbeizhai and Jinya gold deposits, southwestern China: International Geology Review, v. 36, p. 194-202.

Wang, K., Yao, S., Yang, Y., and Dai, J., 2004, Geological characteristics and origin of Manaoke finegrained disseminated gold deposit in northwestern Sichuan Province: Mineral Deposits, v. 23, no. 4, p. 494-501 (in Chinese with English abstract).

Wolfenden, E.B., 1965, Bau mining district, West Sarawak, Malaysia—Part 1, Bau: Malaysia Geological Survey, Borneo Region, Bulletin 7, 147 p.

Ye, Z., Kesler, S.E., Essene, E.J., Zohar, P.B., and Borhauer, J.L., 2003, Relation of Carlin-type gold mineralization to lithology, structure and alteration-Screamer zone, Betze-Post deposit, Nevada: Mineralium Deposita, v. 38, p. 22-38.

Yukon-Nevada Gold Corporation, 2012, Operations_-Jerritt Canyon: Press Release of January, 2012, 10 p., accessed August 8, 2012, at http://www.yukonnevadagold.com/s/JerrittCanyon.asp.

Zaw, K., Peters, S.G., Cromie, P., Burrett, C., and Hou, Z., 2007, Nature, diversity of deposit types and metallogenic relations of south China: Ore Geology Reviews, v. 31, p. 3-47. 


\section{Appendixes}

Appendixes are available for download at http://pubs.usgs.gov/of/2014/1074/.

Appendix 1. Sediment-hosted Au DB.fp8

Appendix 2. Sediment-hosted Au DB.xls

Appendix 3. Sediment-hosted Au DB.tab

Appendix 4. Reference list to sediment-hosted Au deposits DB.doc

Appendix 5. Sediment-hosted Au.kmz

Appendix 6. Definitions of fields of sediment-hosted Au deposits DB.xls 